MICHIGAN RETIREMENT AND DISABILITY RESEARCH CENTER UNIVERSITY OF MICHIGAN

Promoting research on retirement, disability, and Social Security policy

\title{
A Framework for Cost-Benefit Analysis of Totalization Agreements
}

Erik Meijer, Francisco Perez-Arce, and Maria Prados

MRDRC WP 2020-410

UM20-08 


\title{
A Framework for Cost-Benefit Analysis of Totalization Agreements
}

\section{Erik Meijer}

University of Southern California

\author{
Francisco Pérez-Arce
}

University of Southern California

\author{
María Prados \\ University of Southern California
}

September 2020

Michigan Retirement and Disability Research Center, University of Michigan, P.O. Box 1248. Ann Arbor, Ml 48104, mrdrc.isr.umich.edu, (734) 615-0422

\section{Acknowledgements}

The research reported herein was performed pursuant to a grant from the U.S. Social Security Administration (SSA) funded as part of the Retirement and Disability Research Consortium through the University of Michigan Retirement and Disability Research Center Award RDR18000002-01. The opinions and conclusions expressed are solely those of the author(s) and do not represent the opinions or policy of SSA or any agency of the federal government. Neither the United States government nor any agency thereof, nor any of their employees, makes any warranty, express or implied, or assumes any legal liability or responsibility for the accuracy, completeness, or usefulness of the contents of this report. Reference herein to any specific commercial product, process or service by trade name, trademark, manufacturer, or otherwise does not necessarily constitute or imply endorsement, recommendation or favoring by the United States government or any agency thereof.

\section{Regents of the University of Michigan}

Jordan B. Acker; Huntington Woods; Michael J. Behm, Grand Blanc; Mark J. Bernstein, Ann Arbor; Paul W. Brown, Ann Arbor; Shauna Ryder Diggs, Grosse Pointe; Denise llitch, Bingham Farms; Ron Weiser, Ann Arbor; Katherine E. White, Ann Arbor; Mark S. Schlissel, ex officio 


\title{
A Framework for Cost-Benefit Analysis of Totalization Agreements
}

\begin{abstract}
International social security totalization agreements eliminate double social security taxation for workers who reside and work in a different country than their home country. Because totalization agreements affect a number of economic agents in a variety of ways, we develop a cost-benefit framework of totalization agreements to facilitate the comparison and assessment of these impacts from a cost-benefit perspective. It lists the important stakeholders and the types of potential effects of the agreement on them, and attempts to quantify each type of effect for each stakeholder. The framework can be useful to policymakers and researchers to evaluate the economic implications of current or proposed future agreements, depending on economic conditions, characteristics of partner countries, and how they affect different stakeholders. The paper also summarizes what is currently known about the effects and related costs and benefits of totalization agreements. We provide relatively simple and straightforward example calculations for some of these effects, as well as calculations using a stylized micro-economic model for workers and a stylized macroeconomic model for firm investment and production allocation. In a few cases, we have both simple calculations of direct effects and model calculations that take more channels into account (under strong assumptions). They agree well, implying that the simple calculations capture most of the total effect.
\end{abstract}

\section{Citation}

Meijer, Erik, Francisco Pérez-Arce, and María Prados. 2020. "A Framework for Cost-Benefit Analysis of Totalization Agreements." Ann Arbor, MI. University of Michigan Retirement and Disability Research Center (MRDRC) Working Paper; MRDRC WP 2020-410.

https://mrdrc.isr.umich.edu/publications/papers/pdf/wp410.pdf 


\section{Preface}

International social security totalization agreements signed by the United States affect several economic agents. They benefit U.S. nationals who work temporarily in a foreign country and foreigners who work in the U.S. by avoiding dual contributions to the Social Security Administration (SSA) and the signing countries' counterpart agencies, and by reducing the risk of not meeting eligibility requirements such as the minimum number of years of contributions (Jackson and Cash 2018). By facilitating the international reallocation of workers, totalization agreements can affect multinational firms' incentives, foreign direct investment, and international capital flows. Lastly, by determining which foreign workers and which U.S. workers abroad contribute to Social Security payroll taxes, totalization agreements directly impact the revenues of the Social Security Administration.

In prior work (Prados et al. 2019), we developed an international macroeconomic model to quantify the effects of totalization agreements on investment and capital and labor flows. In this project, we expand on this and design a framework for assessing current or proposed future totalization agreements. The cost-benefit framework classifies the potential impacts of totalization agreements, identifying the potential domains of impact and how different stakeholders in the public and private sectors would be affected

We use the cost-benefit framework, together with the assembled empirical evidence, to map existing studies of totalization agreements within the framework. This helps the reader place existing studies and data into perspective. Furthermore, we add analyses of existing data. The study could be of interest to policymakers at all levels of 
government, as well stakeholders in the private sector, who desire to understand how totalization agreements benefit different stakeholders, and how these benefits compare to their cost. 


\section{Abbreviations}

CoC

FDI

GDP

GNP

IRS

OASDI

SSA
Certificate of Coverage

Foreign Direct Investment

Gross Domestic Product

Gross National Product

Internal Revenue Service

Old-Age, Survivors, and Disability Insurance

Social Security Administration 


\section{Introduction}

The United States has signed more than 30 bilateral Social Security agreements, often referred to as "totalization agreements" (TA), with countries in Europe, Asia, North and South America, and Oceania. These agreements coordinate the U.S. Social Security program with other countries' comparable programs. The first such agreement, with Italy, was signed in 1978, and the most recent one, with Iceland, in 2019. Agreements have been signed with both developed and developing nations.

While some important details in the agreements differ across partner countries, their most important components are common to all of them. The agreements mainly do two things: ${ }^{1}$ First, they eliminate the dual social security taxation incurred when a worker must contribute to the social security systems of both the home and host countries, Second, the totalization of benefits reduces the risk of not qualifying to a pension due to "qualifying quarters" being spread across countries: Totalization agreements allow workers under certain cases to combine, or "totalize," coverage credits from both nations.

Totalization agreements, thus, have clear benefits. Not being doubly taxed for social security substantially reduces the cost for multinationals and American companies with foreign affiliates and, importantly, for their workers. The dual social security tax liability is a widespread problem for U.S. multinational companies and the workers they send abroad, particularly because the U.S. tends to have a broader

\footnotetext{
${ }^{1} \mathrm{https}$ ://www.ssa.gov/international/agreements_overview.html. This is also described in some detail in Prados et al. (2019).
} 
coverage of expatriates ${ }^{2}$ than those of other countries since Americans sent abroad always need to pay social security contributions absent totalization agreements.

The counterpart is that, absent a totalization agreement, some foreign workers being sent to the U.S. by companies based abroad would pay taxes to the U.S. Social Security Administration (SSA), but many of them will not have to do so once an agreement is in place. Without a totalization agreement, many of these foreign workers would contribute to the U.S. Social Security only for a few years and never qualify for benefits. Hence, some of those workers could create a windfall for the SSA. This windfall is lost under a totalization agreement; therefore, these treaties also create costs to consider.

To gauge whether to sign a new agreement from the perspective of a U.S. decision-maker, one could compare the benefits for American companies and workers sent abroad with the potential revenue loss to SSA from foreign expatriates who are now exempted by the totalization agreement from contributing to it. However, economic theory and a recent literature suggest this may not paint the complete picture.

Though these are two relatively straightforward, direct effects, the overall impacts of the agreements are likely to go beyond this and indirectly affect many other groups of people. By changing the costs faced by workers and firms, they are likely to have effects on a number of trade and macroeconomic variables. In fact, Seshadri (2019) finds effects on exports and imports (and hence, on trade balances) from different agreements, and Prados et al. (2019) show that their macroeconomic impacts can be

\footnotetext{
${ }^{2}$ https://www.ssa.gov/international/agreements_overview.html
} 
substantial and depend on the partner country's characteristics. It is thus important to consider an agreement's myriad effects and have a sense of how to weigh them.

The list of stakeholders directly affected by totalization agreement includes the following: U.S. nationals working temporarily in a foreign country and foreigners working in the U.S. who avoid dual social security contributions to two countries' agencies; U.S nationals who benefit from a reduction in the risk of not meeting eligibility requirements such as the minimum number of years of contributions (Jackson and Cash 2018); and the agencies in charge of social security, since they affect which foreign workers and which U.S. workers abroad contribute to social security payroll taxes. However, totalization agreements may have effects that go beyond this and hence affect broader stakeholder groups. By facilitating the international reallocation of workers, totalization agreements affect multinational firms' incentives, foreign direct investment, and international capital flows. These indirect effects produce benefits (or costs) for firms and consumers beyond those directly affected by the agreements.

The magnitude of the effects varies across stakeholder groups. The effects on the directly affected workers (those who are sent to the partner country) and on the social security agencies' balances will be first order, while the indirect effects (such as the impacts through macroeconomic effects) will be smaller per capita but widereaching.

The cost-benefit framework can be useful from both normative and positive analyses. From the normative point of view, analysts could use our framework to conduct calculations of a prospective totalization agreement's likely benefits and costs that would be accrued to domestic stakeholders and use that to recommend for or 
against an agreement. From the positive analysis point of view, the cost-benefit framework could be used to understand the "political economy" that may determine why certain agreements are or are not signed, which may occur, for example, when a totalization agreement with certain countries would imply substantial costs to specific stakeholders that could oppose the signing of an agreement.

\section{Preamble}

\subsection{Notes on terminology}

For better readability, we use a series of short-hands throughout this document. Some of these terms require clarification.

First, we note that we use American workers through this document as a shorthand for all workers who are treated as such by U.S. law, which may include foreign nationals who are U.S. permanent residents. Likewise, a national of the partner country is any person who is treated as such by the partner country's corresponding laws.

Social security contributions in the U.S. go to trust funds that are used to disburse benefits. For instance, retirement and disability benefits are paid out of the Old-Age and Survivors Insurance (OASI) and Disability Insurance (DI) trust funds, respectively, which are formally separate but jointly managed. Therefore, we follow Pattison (2015) and treat these as one Old-Age, Survivors, and Disability Insurance (OASDI) trust fund. For readability, we refer to inflows and outflows of those funds as being benefits to the $S S A$, but that should be understood as benefits or costs to beneficiaries and other stakeholders of the OASDI funds. 
2.2 How totalization agreements change the rules for expatriate workers and their employers

In this section, we describe the two main changes that totalization agreements achieve. First, we describe how a totalization agreement affects current workers by allowing them to avoid double taxation, which also affects the cash flow to the social security agencies. Second, we describe how a totalization agreement can affect individuals who need to combine the contributions made to both countries' social security in order to pass the threshold to receive benefits from the domestic social security administration.

\subsubsection{Double taxation}

Totalization agreements affect the taxes paid and benefits received by workers. For American workers who work for an American firm or are self-employed temporarily in a foreign country for a period of five years or less, totalization agreements do not affect their duties with respect to U.S. Social Security taxes. On the other hand, these workers will typically have to pay taxes to the partner country's social security agency if there is no totalization agreement in place. If, on the other hand, the country does have a bilateral social security agreement with the U.S., the totalization agreement avoids double taxation for that worker.

Table 2.1 shows all the separate cases. The highlighted rows represent the cases for which the totalization agreement makes a material difference for the stakeholders.

The first case, depicted in the first row of the table, corresponds to Americans working for an American firm, who are sent to the partner country to work for an affiliate 
of the parent company for a period no longer than five years. The same qualitative effects apply for self-employed Americans who conduct their work activities in the partner country with the intent of staying for five or fewer years. Hence, we include these in the same row, as the effects are of the same magnitude.

For these workers, U.S. laws require the worker to make contributions to U.S. Social Security. Most foreign countries would also require them to make contributions to their local social security system ${ }^{3}$ and, hence, these workers are taxed doubly for social security. U.S. taxes are levied upon both workers and their employer, and this is the case in most other countries as well, so both the firm and the employee need to contribute to both systems.

Totalization agreements eliminate double taxation for this group of workers, which totalization agreements refer to as "detached workers." 4 They are considered the exception to the rule and, thus, instead of paying contributions to the host countries, they do so to the one with greater economic attachment. Workers deemed to have greater economic attachment to the U.S. can obtain from SSA a Certificate of Coverage $(\mathrm{CoC})$. While their period in the partner country lasts, they can use the $\mathrm{CoC}$ to demonstrate their exemption from that country's social security taxes. Hence, totalization agreements change the situation for these workers from having to pay social security taxes to both systems to having to pay them only in the U.S. This row is

\footnotetext{
${ }^{3}$ This is certainly the case for Japan and Germany, but is also true of most countries with social security systems.

${ }^{4}$ Source: IRS https://www.irs.gov/government-entities/federal-state-localgovernments/totalization-agreements.
} 
highlighted to denote a material change for this group of workers due to the totalization agreement.

Generally, however, Americans who gain employment while abroad, for either an American or a domestic firm, are not required to pay contributions to the U.S. Social Security system. This is because, for them, the totalization agreement applies the territoriality rule which means that workers should pay taxes and be covered under the social security system of only one country, which is usually where they are employed (the exception being for detached workers covered in the case above). The totalization agreement does not affect them, as these workers cannot get a certificate of coverage and would likely still be paying only the foreign taxes. Hence, as shown in the second and third rows of the table, totalization agreements do not change the situation for them

Row four also shows that there are no changes associated to a totalization agreement's signing for workers employed long-term in the partner country. The totalization agreement determines the contributions to social security go to the country with "greater economic attachment" and, in the case of longer stays, the country of greater economic attachment becomes the host country: The totalization agreement does not change anything for these workers. Generally, the maximum period for a totalization agreement to apply is five years, though there are some cases when the five-year period in the $\mathrm{CoC}$ can be renewed. 
Table 2.1. Social Security taxes: Effects of a Totalization agreement. Stylized case based on the agreements with Japan and Germany

\begin{tabular}{|l|l|l|}
\hline Types of worker & Without TA & With TA \\
\hline $\begin{array}{l}\text { Americans working abroad temporarily }(<\mathbf{5} \\
\text { years) for U.S. firm and self-employed } \\
\text { (temporarily) }\end{array}$ & $\begin{array}{l}\text { Pay OASDI taxes } \\
\text { Pay foreign social } \\
\text { security taxes }\end{array}$ & $\begin{array}{l}\text { Pay OASDI taxes } \\
\text { Do not pay foreign } \\
\text { social security taxes }\end{array}$ \\
\hline $\begin{array}{l}\text { Americans working temporarily }(<\mathbf{5} \text { years) for } \\
\text { American firm abroad when hired while abroad } \\
\text { Do not pay OASDI } \\
\text { taxes } \\
\text { Pay foreign social } \\
\text { security taxes }\end{array}$ & $\begin{array}{l}\text { Do not pay OASDI } \\
\text { taxes } \\
\text { Pay foreign social } \\
\text { security taxes }\end{array}$ \\
\hline $\begin{array}{l}\text { Americans working temporarily }(<\mathbf{5} \text { years) for } \\
\text { foreign firm abroad, } \\
\text { Or if hired while abroad }\end{array}$ & $\begin{array}{l}\text { Do not pay OASDI } \\
\text { taxes } \\
\text { Pay foreign social } \\
\text { security taxes }\end{array}$ & $\begin{array}{l}\text { Do not pay OASDI } \\
\text { taxes } \\
\text { Pay foreign social } \\
\text { security taxes }\end{array}$ \\
\hline $\begin{array}{l}\text { Americans working abroad long term } \mathbf{( > 5} \text { years) } \\
\text { abroad for foreign firm or when hired abroad } \\
\text { Do not pay OASDI } \\
\text { taxes } \\
\text { Pay foreign taxes } \\
\text { taxes } \\
\text { Pay foreign social } \\
\text { security taxes }\end{array}$ \\
\hline $\begin{array}{l}\text { Americans working abroad long term } \mathbf{( > 5} \text { years) } \\
\text { for U.S. firm } \\
\text { and self-employed going long term }\end{array}$ & $\begin{array}{l}\text { Pay OASDI taxes } \\
\text { Pay foreign social } \\
\text { security taxes }\end{array}$ & $\begin{array}{l}\text { Do not pay OASDI } \\
\text { Pay foreign social } \\
\text { security taxes }\end{array}$ \\
\hline $\begin{array}{l}\text { Partner-country nationals working temporarily } \\
\text { in the U.S. }\end{array}$ & Pay OASDI taxes & $\begin{array}{l}\text { Do not pay OASDI } \\
\text { taxes }\end{array}$ \\
\hline $\begin{array}{l}\text { Partner-country nationals working long term } \\
\text { (>5 years) in the U.S. }\end{array}$ & Pay OASDI taxes & $\begin{array}{l}\text { Do not pay OASDI } \\
\text { taxes }\end{array}$ \\
\hline
\end{tabular}

The mirror image of these effects applies to the partner country's nationals who come to work in the U.S. In the absence of an international agreement, the U.S requires everyone working in the U.S. to pay Social Security taxes. Partner-country nationals working in the U.S. for less than five years would pay Social Security taxes if no totalization agreement is in place, but would be exempt from doing so under a totalization agreement as they could get a CoC from their country certifying that they are covered there and are not required to pay OASDI taxes.

As shown in the last row of Table 2.1, for partner-country nationals who are coming to the U.S. long term, the totalization agreement would not change the requirement that they contribute to the U.S. Social Security system. 


\subsubsection{Totalization of benefits}

As explained in the introduction, the term "totalization" derives from the provision through which they allow workers to combine, or "totalize," coverage credits from both nations. This is also sometimes referred to as the "benefit provision" of totalization agreements

The second large area of impacts of these agreements lies in this totalization aspect. The totalization of benefits helps people who would be at risk of not qualifying for social security benefits due to not earning enough credits, for instance, by not having contributed in the 40 qualifying quarters required in the U.S. to be eligible for Social Security retirement benefits. For an individual who spends time in many countries and hence contribute to several systems, it may be challenging to achieve the minimum quantity of qualifying quarters.

\subsection{A preamble on cost-benefit analysis}

Before creating the framework for totalization agreements, it is important to explain some basic concepts about cost-benefit analyses. Some of the terminology may be confusing for those unfamiliar with these concepts. For example, in the context of a cost-benefit analysis, the terms benefit and cost refers to the increased (reduced) welfare associated to the policy being analyzed, and not necessarily to the accounting benefit and cost. For example, we refer to income that could be expected to be accrued to an agency absent a totalization agreement as a "cost" even though it would not be an actual expense that is reported in the accounting.

Cost-benefit analyses provide a framework to assess a policy or program. In order to do this, it is necessary to translate into dollar amounts the range of outcomes 
and the degree that they produce different kinds of benefits (and costs). This is often challenging as it is often the case that these benefits and costs are nonmonetary. For the case of totalization agreements, most of the benefits and costs are financial and naturally reported in dollar terms. For instance, individuals who benefit from the removal of double taxation see an increased after-tax income, and the social security agencies that stop receiving those taxes see a cost in the form of foregone revenue.

There are a couple of instances, however, where we do need to translate into dollars benefits or costs that are nonmonetary. Different methodologies are used for this purpose. These benefits and costs are often referred to as shadow prices. One such case is when totalization agreements change the location decisions of employees, which may result in income effects but also nonmonetary costs or benefits for moving abroad. We created a micromodel of workers' lifetime utility in order to provide some insights into this. The second case is where totalization agreements result in increased international trade. Trade may result in higher income for firms, but may also result in increased options for consumers, which also has to be accounted for in the cost-benefit analysis.

Cost-benefit analyses usually need to account for effects that are expected to happen throughout many years. To do so, they use discount rates to bring future values into todays' dollars using Present Discounted Values. In contrast, most of the costs and benefits of totalization agreements occur contemporaneously (especially after an introduction phase), and there is no a priori reason to think that costs would rise more or less than benefits over time. Hence, for the purposes of constructing summary statistics such as the benefit-cost ratio, it is enough to calculate yearly costs and benefits. Since 
costs and benefits would rise or fall proportionally across time, the cost-benefit ratio would not be affected by the discount rate used. Hence, we create the cost-benefit analysis framework using one-year values. ${ }^{5}$

As mentioned in the introduction, the objective is to provide a framework that can be used to guide prospective cost-benefit analyses. Ultimately, those doing a costbenefit analysis will be interested in a summary indicator such as the benefit-cost ratio. However, a unique, certain result for this number will not always be achievable. First, because the data we recommend using may not be available. Second, because the parameters we identify from the literature have some uncertainty themselves or are only proxies.

Perhaps at least as important as a final number, is the visualization of the different types of effects and how they affect different stakeholders. These can be used, for example, to understand why different stakeholders may have different positions with respect to the totalization agreements. This also allows one to analyze effect subsets, or effects for stakeholder subsets. For example, some uses of the framework may be to analyze only domestic stakeholders, or only look at the totalization agreements' direct fiscal implications.

\footnotetext{
${ }^{5}$ We discuss one exception for analyses that integrate benefits from the microeconomic model derived from lifetime utility in a life-cycle model. In order to do this, we estimate the yearly amount that the expatriate would be willing to pay per year of their period abroad in order to equalize the lifetime utility flows under the scenarios of existence and absence of totalization agreements.
} 


\section{Building up a Framework for Cost-Benefit Analyses of Totalization}

\section{Agreements}

The family of first-order totalization agreements' effects are those that accrue to those directly affected by them: namely, 1) the workers (and firms who send them) no longer required to pay double social security taxes, 2) those who become eligible for social security benefits thanks to the totalization agreements, and 3) the social security agencies who stop receiving the extra contributions and have to pay the "totalized" benefits per points 1 ) and 2). These effects occur in relation to workers who would have been relocated regardless of the agreement's existence. In this sense, we refer to them as the effects that occur regardless of behavioral responses. We refer to the workers (and firms who send them) whose temporary move to the partner country would occur regardless of the totalization agreement as always takers, adopting terminology introduced in the treatment effects literature by Angrist et al. (1996).

A first step when assessing a new agreement is to count how many workers and firms would be affected absent behavioral responses to the changes induced, and then to assess the magnitude of these changes per worker or beneficiary.

3.1 Benefits and costs arising from the activities of expatriate workers who would work abroad in the absence of a totalization agreement (always takers)

In this first step, we consider the people who would be sent abroad temporarily by American firms, and those who would come from abroad to work here temporarily (and the foreign firms they work for) even if there was no totalization agreement.

Absent a totalization agreement, these workers are subject to double taxation. They have to pay not only their contribution to U.S. Social Security, but also, in most 
cases (depending on the host country's laws), to the host country's counterpart agency. With a totalization agreement, they would stop having to contribute to the host country.

In the cost-benefit framework, this is a net benefit to the American worker and the firm where she works. The extent to which the benefit accrues to the worker or the firm, depends on whether the host country requires both the employee and employer to make contributions, and also to the extent that the firm increases the employee's pay to compensate for the double taxation, which, theoretically, would depend on the worker's outside options and the going market-clearing wage.

The counterpart for this is the cost to the partner country's social security agency, as they would lose the contribution from the American worker and firm. The benefit to the firm and worker is highlighted in green in the first row of Table 3.1, while the cost to the foreign social security agency is highlighted in red.

The corresponding costs and benefits relating to the foreign workers sent to the U.S. who would have been sent regardless of the presence of a totalization agreement are shown in the second row. It summarizes the costs and benefits associated with the elimination of double taxation for this group. Absent a totalization agreement, the "always taker" partner-country expat contributes to U.S. Social Security and may be double taxed, depending on whether her home country requires her to contribute. A totalization agreement would allow the foreign worker to contribute to her home social security program and not to the American one. So, it would be a net benefit for the foreign worker as she either avoids double taxation or is able to channel her contribution to the program she would benefit from, and is a cost for the SSA as it stops receiving a contribution. 
Table 3.1. The Impacts of totalization agreements through the effects on "alwaystaker" expatriate workers.

\begin{tabular}{|c|c|c|c|}
\hline Types of worker & $\begin{array}{l}\text { Without } \\
\text { TA }\end{array}$ & With TA & Impacts of TA \\
\hline \multirow[t]{2}{*}{$\begin{array}{l}\text { Americans working } \\
\text { abroad for U.S. firm or } \\
\text { self-employed }\end{array}$} & \multirow{2}{*}{$\begin{array}{l}\text { Pay } \\
\text { OASDI } \\
\text { taxes } \\
\text { Pay } \\
\text { foreign } \\
\text { taxes }\end{array}$} & \multirow{2}{*}{$\begin{array}{l}\text { Pay OASDI } \\
\text { taxes } \\
\text { Do not pay } \\
\text { foreign } \\
\text { taxes }\end{array}$} & $\begin{array}{l}\text { Increase disposable income for } \\
\text { American expats/reduced expenses } \\
\text { for American firm }\end{array}$ \\
\hline & & & $\begin{array}{l}\text { Reduction in income for foreign social } \\
\text { security institution }\end{array}$ \\
\hline \multirow{2}{*}{$\begin{array}{l}\text { Partner-country nationals } \\
\text { working temporarily in the } \\
\text { US }\end{array}$} & \multirow[t]{2}{*}{$\begin{array}{l}\text { Pay SSA } \\
\text { taxes }\end{array}$} & \multirow{2}{*}{$\begin{array}{l}\text { Do not pay } \\
\text { OASDI } \\
\text { taxes }\end{array}$} & $\begin{array}{l}\text { Increase income for foreign expat } \\
\text { coming to America }\end{array}$ \\
\hline & & & Reduction in income for SSA \\
\hline
\end{tabular}

3.2 Benefits and costs arising through the effect of increasing expatriate worker flows (the added-expatriate worker effect)

The list of benefits and costs does not stop with the direct effects discussed in section 3.1. Totalization agreements also can produce behavioral impacts. In the same way the quantity demanded for a good increases when the price is lowered, the number of expatriates being sent in and out of the U.S. responds to a totalization agreement's signing that reduces the cost for the firm and employee of being sent abroad. Hence, we can anticipate totalization agreements to have an effect on the number of affected employees and firms. We refer to this as the added expatriate worker effect, and to these additional expatriate workers as induced expatriates in the sense that it is the presence of the agreement that made them (or "induced them") to move abroad (or their employer to send them).

Furthermore, induced expatriates' benefits and costs will be different than those of always takers. For workers induced to move, the benefit is not higher than for the 
always takers, and it may be lower. The benefit for them lies somewhere between zero and the benefit for the always-taker. We know there is still a benefit for them, since with the totalization agreement they still have the option not to move, so given that they do, it means that they are better off. In economics, this is called the revealed preference argument. ${ }^{6}$ To see why the benefit has to be lower than that for always-takers, consider the fact that, absent a totalization agreement, they would not have moved so by definition the move's utility was negative. Call this utility $u$ and it is a shorthand for the combined utility for the employer and the employee. The totalization agreement means a benefit of the amount of reduced taxation, call it $T A$, which is the always takers' total benefit. Call the benefit for the induced workers $T I=u+T A$. Since they decide to move given a totalization agreement, we know that $0<T I=u+T A<T A$, which implies that the benefit for them will be somewhere between zero and the always takers' increase in disposable income. To avoid making the discussion here too technical, we refer the interested reader to Appendix 1, where we describe a microeconomic theoretical model of these decisions, and where we show how one can go about measuring or estimating the utility's value.

From this particular effect (first row in Table 3.2), for the foreign social security institution, the costs would be null as it is no longer the case that, absent an agreement, they would have collected contributions. In this case, they do not collect contributions regardless of the totalization agreement's existence, so the positive benefit for the

\footnotetext{
${ }^{6}$ As before, we note that how much of this utility accrues to the employer or the employee cannot be disentangled, and it is possible that that the employer has to pay an extra incentive in order to realize this "utility."
} 
induced workers does not have a counterpart negative effect for either social security agency.

The mirror image effects accrue for the foreign incoming expat coming temporarily. The benefit for the expat whose decision is affected by the signing of the totalization agreement is also positive but lower than for those who would have come to the U.S. regardless. Likewise, there is no cost associated to the U.S. Social Security Administration since it would not be receiving contributions in either case.

Table 3.2. The Impacts of totalization agreements through the added expatriate worker effect.

\begin{tabular}{|l|l|l|l|}
\hline Types of worker & Without TA & With TA & Impacts of TA \\
\hline $\begin{array}{l}\text { Americans working } \\
\text { abroad temporarily (<5 } \\
\text { years) for U.S. firm }\end{array}$ & $\begin{array}{l}\text { Stays in U.S. } \\
\text { Pay OASDI taxes } \\
\text { Does not pay foreign } \\
\text { taxes }\end{array}$ & $\begin{array}{l}\text { Moves abroad } \\
\text { Pay OASDI taxes } \\
\text { Does not pay foreign } \\
\text { taxes }\end{array}$ & $\begin{array}{l}\text { Positive benefit to } \\
\text { the expat/firm who } \\
\text { sends abroad } \\
\text { (revealed } \\
\text { preference } \\
\text { argument) }\end{array}$ \\
\hline $\begin{array}{l}\text { Foreign nationals } \\
\text { working temporarily in } \\
\text { the U.S. }\end{array}$ & $\begin{array}{l}\text { Stays in foreign } \\
\text { country } \\
\text { Does not pay OASDI } \\
\text { taxes } \\
\text { Pays taxes in home } \\
\text { SS agency }\end{array}$ & $\begin{array}{l}\text { Moves to U.S. } \\
\text { Do not pay OASDI } \\
\text { Pays taxes in home } \\
\text { SS agency. }\end{array}$ & $\begin{array}{l}\text { Positive benefit to } \\
\text { foreign expat } \\
\text { coming to America }\end{array}$ \\
\cline { 2 - 3 } & $\begin{array}{l}\text { No effect in income } \\
\text { for social security } \\
\text { institutions }\end{array}$ \\
\hline
\end{tabular}

\subsection{Benefits and costs from the totalization provision}

The other direct impact that totalization agreements have is through their "totalization" aspect. This represents a benefit for some former workers who would not otherwise have qualified for disability or retirement benefits. For some people, this aspect of totalization agreements means that they will receive at least some benefit 
income instead of nothing. The Social Security Administration then faces a financial cost, as they need to pay some benefits that they otherwise would not have to. Note that this is different from the benefit above, where the cost that mirrors the benefit from removed double taxation is borne by the partner country agency. Here, it is borne by the SSA.

The social security agencies pay benefits proportionally for the years contributed to each country. Hence, someone who totalizes the quarters to meet the minimum required periods may receive payments from both agencies. As described in Jackson and Cash (2018): "the amount of the U.S. benefit payable is proportional only to those periods of coverage earned in the United States. The partner country similarly pays a partial, or prorated, benefit when combined coverage establishes entitlement."

The first row of Table 3.3 shows the benefits for the American individuals who due to the totalization agreement, are able to combine the contributions and receive some benefits from social security programs. As indicated in the second row of Table 3.3, for the foreign former workers who become able to "totalize," the benefit is accrued to themselves, while the cost is borne by the foreign social security agency (or agencies) now paying a benefit that it would not have to pay absent a totalization agreement. 
Table 3.3. The Impacts of totalization agreements through the benefit provision

\begin{tabular}{|l|l|l|l|}
\hline Types of worker & Without TA & With TA & Impacts of TA \\
\hline $\begin{array}{l}\text { Americans who } \\
\text { become able to } \\
\text { "totalize" benefits due } \\
\text { to the totalization } \\
\text { agreement }\end{array}$ & $\begin{array}{l}\text { May fall short of the } \\
\text { number of contributed } \\
\text { quarters and be } \\
\text { ineligible for benefits }\end{array}$ & $\begin{array}{l}\text { May surpass the } \\
\text { threshold of 40 } \\
\text { contributed quarters } \\
\text { required for } \\
\text { retirement benefits in } \\
\text { SSA and/or the } \\
\text { threshold to receive } \\
\text { benefits from partner } \\
\text { country }\end{array}$ & $\begin{array}{l}\text { Increase income for } \\
\text { the beneficiaries } \\
\text { who totalize } \\
\text { benefits }\end{array}$ \\
\cline { 3 - 4 } & $\begin{array}{l}\text { Increased expenses } \\
\text { for the SSA and } \\
\text { partner country } \\
\text { social security } \\
\text { agency }\end{array}$ \\
\hline $\begin{array}{l}\text { Partner-country } \\
\text { nationals who become } \\
\text { able to "totalize" } \\
\text { benefits due to the } \\
\text { totalization agreement }\end{array}$ & $\begin{array}{l}\text { May fall short of the } \\
\text { number of contributed } \\
\text { years and be ineligible } \\
\text { for benefits }\end{array}$ & $\begin{array}{l}\text { May surpass the } \\
\text { threshold set by the } \\
\text { partner country for } \\
\text { benefit eligibility } \\
\text { and/or threshold of } 40 \\
\text { contributed quarters } \\
\text { required for benefits } \\
\text { from SSA }\end{array}$ & $\begin{array}{l}\text { Increase income for } \\
\text { the beneficiaries } \\
\text { who totalize } \\
\text { benefits }\end{array}$ \\
$\begin{array}{ll}\text { Increased expenses } \\
\text { for the partner } \\
\text { agency and SSA }\end{array}$ \\
\hline
\end{tabular}

3.4 Further benefits and costs: Firms and aggregate effects - multinational production and international trade.

While taking into account the "added-expat" effect certainly makes for a more complete evaluation of the agreements, it does not encompass all possible factors that may affect the costs and benefits. Totalization agreements affect incentives and behaviors of multinational firms and facilitate labor reallocation for multinational firms (Carey 1993, Larkins 1993, Russo and D'Onofrio 1995). Recently, two studies have investigated the possibility that totalization agreements may have macroeconomic effects (Seshadri 2019, and Prados et al. 2019). This implies that other stakeholders in a country may be affected in addition to the expatriates, the firms that employ them, and social security administrations' finances.

Totalization agreements lower the costs of firms sending workers to affiliates in the partner country. If the cost reduction implied by the elimination of double taxation is 
enough to make investments in that country profitable enough, ${ }^{7}$ this may allow firms to expand their investments abroad and benefit from lower production costs abroad, and likewise in the other direction. Multinational production serves foreign markets by allowing firms to avoid such costs as transport that affect international trade flows. This reflects a gain accrued for the firms that make such investments, as shown in the first cell of the benefit-cost matrix in Table 3.4. On the other hand, this could also mean more competition for some same-industry firms operating in the host country, while other local firms may gain from synergies with the additional investments. Overall, FDI may have benefits for the population at large to the extent it contributes to economic growth.

The effects would be reversed for incoming FDI. The firm making the investments likely gained from the improved investment opportunities. There may be some domestic firms with losses due to the increased competition, but also ones that may benefit from production chains or other synergies with firms that employ the foreign workers sent to the U.S. To the extent that the foreign investment contributes to the economy's dynamism, there may be benefits interspersed through the population via economic growth.

\footnotetext{
${ }^{7}$ The allocation of managerial power in the model in Prados et al. (2019) implies that the firms equalize after-tax benefits from domestic and foreign operations.
} 
Table 3.4 The impacts of totalization agreements through FDI

\begin{tabular}{|l|l|l|l|l|}
\hline \multirow{2}{*}{$\begin{array}{l}\text { Type of } \\
\text { macroeconomic } \\
\text { effect }\end{array}$} & Affected firms & \multicolumn{3}{|l|}{ Economy and population at large } \\
\cline { 3 - 5 } & & Other firms & $\begin{array}{l}\text { Capital } \\
\text { holders }\end{array}$ & $\begin{array}{l}\text { Population at } \\
\text { large }\end{array}$ \\
\hline Effect of FDI & & & & \\
\hline Outgoing FDI & $\begin{array}{l}\text { Signals increased } \\
\text { business } \\
\text { opportunities } \\
\text { abroad for } \\
\text { American } \\
\text { investors. }\end{array}$ & $\begin{array}{l}\text { Possibly } \\
\text { increased } \\
\text { competition to } \\
\text { firms in the foreign } \\
\text { country. }\end{array}$ & $\begin{array}{l}\text { Most likely } \\
\text { an } \\
\text { oppossibly } \\
\text { synergetic } \\
\text { investment } \\
\text { opportunities. } \\
\text { abroad }\end{array}$ & $\begin{array}{l}\text { Effects in } \\
\text { opposite } \\
\text { directions: } \\
\text { Reduced } \\
\text { domestic } \\
\text { production } \\
\text { versus } \\
\text { increased } \\
\text { revenues to } \\
\text { domestic factors } \\
\text { abroad. }\end{array}$ \\
\hline Incoming FDI & $\begin{array}{l}\text { Results from } \\
\text { increased } \\
\text { business } \\
\text { opportunities in } \\
\text { the U.S. for } \\
\text { foreign firms }\end{array}$ & $\begin{array}{l}\text { Possibly } \\
\text { increased } \\
\text { competition to } \\
\text { firms in the U.S. } \\
\text { Possibly } \\
\text { synergetic } \\
\text { investment } \\
\text { opportunities for } \\
\text { firms in the U.S. }\end{array}$ & $\begin{array}{l}\text { Most likely } \\
\text { an } \\
\text { opportunity } \\
\text { to repatriate } \\
\text { capital or to } \\
\text { attract } \\
\text { foreign } \\
\text { capitals }\end{array}$ & $\begin{array}{l}\text { Effects in } \\
\text { opposite } \\
\text { directions: } \\
\text { Increased } \\
\text { domestic } \\
\text { production } \\
\text { versus } \\
\text { payments to } \\
\text { foreign factors } \\
\text { producing in the } \\
\text { country. }\end{array}$ \\
\hline & & & $\begin{array}{l}\text { General gains to } \\
\text { the population } \\
\text { (need to ensure } \\
\text { no double } \\
\text { counting) }\end{array}$ \\
\hline
\end{tabular}

Totalization agreements can have impacts on international trade. From a theoretical perspective, the net revenues to the firm's investments are payments to domestic factors abroad, and that has first order effects on the capital account and the trade balance. Additionally, it is possible that multinationals' foreign affiliates use imported inputs from their home country (intrafirm trade). Multinational firms may also use a third country as a "bridge," or export platform, to serve a particular market from 
there. ${ }^{8}$ Lastly, facilitating the flow of expatriate workers across partnered nations may allow some firms to promote their goods for exporting to the partner country, establish partnerships for multinational production chains, etc.

Effects on trade then expand the group of affected stakeholders to much broader swaths of the population. The agreements impact not only the workers and firms that are directly affected, but also the competitor firms, and consumers. Costinot and Rodríguez-Clare (2014) conduct a survey of the literature measuring gains from trade. Table 3.5 below outlines some of these effects. An increase in exports plausibly benefits the exporting firm and possibly its workers, but it may benefit other workers indirectly as well — for example, if it adds to labor demand. An increase in imports may reflect consumers benefitting from new, better, or cheaper products produced in the partner country. In both cases, the increased activity may simply reflect a relocation of product's production or of an intermediate good, where a company is relocating part of their production to or from the partner country.

\footnotetext{
${ }^{8}$ Ramondo and Rodríguez-Clare (2013) refer to the empirical evidence for intrafirm trade and
} include these channels in their model. 
Table 3.5. The impacts of totalization agreements through effects on trade

\begin{tabular}{|c|c|c|c|c|c|c|}
\hline \multirow{2}{*}{$\begin{array}{l}\text { Type of } \\
\text { trade } \\
\text { effect }\end{array}$} & \multicolumn{3}{|c|}{ U.S. Stakeholders } & \multicolumn{3}{|c|}{ Partner country stakeholders } \\
\hline & $\begin{array}{l}\text { Affected } \\
\text { firms/worke } \\
\text { rs in } \\
\text { affected } \\
\text { firms }\end{array}$ & $\begin{array}{l}\text { Other } \\
\text { firms/oth } \\
\text { er } \\
\text { workers }\end{array}$ & $\begin{array}{l}\text { Consumer } \\
\mathrm{s}\end{array}$ & $\begin{array}{l}\text { Affected } \\
\text { firms/worke } \\
\text { rs in } \\
\text { affected } \\
\text { firms }\end{array}$ & \begin{tabular}{|l|} 
Other \\
firms/oth \\
er \\
workers
\end{tabular} & $\begin{array}{l}\text { Consumer } \\
\mathrm{s}\end{array}$ \\
\hline $\begin{array}{l}\text { Increase } \\
\text { d } \\
\text { exports } \\
\text { (increase } \\
\text { d } \\
\text { imports } \\
\text { for } \\
\text { partner } \\
\text { country) }\end{array}$ & $\begin{array}{l}\text { Increased } \\
\text { business } \\
\text { opportunities }\end{array}$ & $\begin{array}{l}\text { Increased } \\
\text { competitio } \\
\mathrm{n} \text { to other } \\
\text { U.S.- } \\
\text { exporting } \\
\text { firms }\end{array}$ & N.A & $\begin{array}{l}\text { Increased } \\
\text { competition } \\
\text { for foreign } \\
\text { and } \\
\text { domestic } \\
\text { firms }\end{array}$ & $\begin{array}{l}\text { Increased } \\
\text { competitio } \\
\mathrm{n} \text { for } \\
\text { partner } \\
\text { country } \\
\text { firms }\end{array}$ & $\begin{array}{l}\text { Increased } \\
\text { consumpti } \\
\text { on } \\
\text { opportuniti } \\
\text { es }\end{array}$ \\
\hline $\begin{array}{l}\text { Increase } \\
\text { d } \\
\text { imports } \\
\text { (increase } \\
\text { d } \\
\text { exports } \\
\text { for } \\
\text { partner } \\
\text { country) }\end{array}$ & $\begin{array}{l}\text { Increased } \\
\text { competition } \\
\text { for domestic } \\
\text { firms }\end{array}$ & $\begin{array}{l}\text { Increased } \\
\text { competitio } \\
\mathrm{n} \text { for } \\
\text { domestic } \\
\text { firms }\end{array}$ & $\begin{array}{l}\text { Increased } \\
\text { consumptio } \\
n \\
\text { opportunitie } \\
\text { s. }\end{array}$ & $\begin{array}{l}\text { Increased } \\
\text { business } \\
\text { opportunities }\end{array}$ & $\begin{array}{l}\text { Increased } \\
\text { competitio } \\
\mathrm{n} \text { to other } \\
\text { partner } \\
\text { country } \\
\text { exporting } \\
\text { firms }\end{array}$ & \\
\hline
\end{tabular}

As we thread into these broader, more dispersed effects, the number of stakeholders and the minutia of how different groups of people are affected grow exponentially, and accounting of the individual costs and benefits becomes impossible. We can, however, aim to approximate the overall direction and magnitude of costs and benefits by relying on economic theory. We discuss this more in the following section.

Of course, the magnitude of the totalization agreements' aggregate effects may be small in per capita terms, especially if the partner country is a small economy. However, these effects could be important from a cost-benefit perspective. First, even if they are small in per capita terms, they affect a large number of people. Second, if they are small overall, they may still be large relative to the agreements' costs (for instance, 
the totalization agreements' fiscal costs to SSA would represent a minuscule fraction of GDP). We discuss the valuation of the costs and benefits in more detail in the following section.

\subsection{Combining the individual effects into an overall framework}

We combine the set of impacts described in Tables 3.1-3.5 into an overall framework describing the wide set of impacts that totalization agreements may have, which are shown in Table 3.6. The organizing principle is based on the approach used in Karoly and Perez-Arce (2016). The framework forms a basis for evaluating totalization agreements by comparing multiple impacts, shown in the table's rows. The columns represent the general stakeholder groups. The matrix cells show the benefits and costs emanating from each effect group to each stakeholder group.

The analyst may choose to focus on only a subset of the costs and benefits, for instance by only analyzing the ones that accrue agents in one of the two countries, or focus only on the costs and benefits for the public sector, or more broadly on effects for all economic agents.

We divide the table into two panels due to space, as placing all the columns horizontally would make the table too wide. The first panel includes only U.S.

stakeholders, while the second panel includes the partner country's stakeholders. Note, however, that the partner country's panel is conceptually the same as the one for the home country, although of course the numbers change due to different tax rates, income levels, trade levels, etc., as we discuss in the following section.

The rows correspond to the impacts discussed above. They are divided into the four large groups corresponding to the earlier tables: effects on the workers sent 
abroad, effects on the firms who send workers abroad, the Social Security

Administration finances (or its corresponding agency abroad), and the population at large. 
Table 3.6. General cost-benefit matrix

\begin{tabular}{|c|c|c|c|c|}
\hline \multirow[t]{2}{*}{ Effect group } & \multicolumn{4}{|c|}{ Benefits and costs for U.S. stakeholders } \\
\hline & $\begin{array}{l}\text { U.S. expats and } \\
\text { former expats }\end{array}$ & $\begin{array}{l}\text { Social Security } \\
\text { Administration }\end{array}$ & $\begin{array}{l}\text { U.S. Affected firms (those } \\
\text { that employ expats to } \\
\text { partner country) }\end{array}$ & $\begin{array}{l}\text { U.S. economy and population at } \\
\text { large }\end{array}$ \\
\hline $\begin{array}{l}\text { Impacts from } \\
\text { current always } \\
\text { takers expats }\end{array}$ & $\begin{array}{l}\text { The income of U.S. } \\
\text { always takers expats } \\
\text { increases by the } \\
\text { reduction in amount } \\
\text { they owe to foreign } \\
\text { social security } \\
\text { administration (shared } \\
\text { with firm) }\end{array}$ & $\begin{array}{l}\text { Forego revenue by the } \\
\text { amount they used to receive } \\
\text { from expats from partner } \\
\text { country }\end{array}$ & $\begin{array}{l}\text { U.S. firms experience a reduction } \\
\text { in amount they owe to foreign } \\
\text { social security organization from } \\
\text { the expats they would have sent } \\
\text { with or without totalization } \\
\text { agreements (shared with expat) }\end{array}$ & -- \\
\hline $\begin{array}{l}\text { Impacts from } \\
\text { added-worker } \\
\text { effect }\end{array}$ & $\begin{array}{l}\text { The income of induced } \\
\text { expats increases } \\
\text { between } 0 \text { and the } \\
\text { amount of the increase } \\
\text { for U.S. always taker } \\
\text { expats. (shared with } \\
\text { firm) }\end{array}$ & -- & $\begin{array}{l}\text { Reduced cost for firms from the } \\
\text { workers they decide to send } \\
\text { (shared with expat) }\end{array}$ & -- \\
\hline $\begin{array}{l}\text { Impacts from the } \\
\text { benefit provision }\end{array}$ & $\begin{array}{l}\text { Some former workers } \\
\text { become able to receive } \\
\text { benefits by combining } \\
\text { qualifying quarters to } \\
\text { surpass } 40 \text { quarter } \\
\text { minimum }\end{array}$ & $\begin{array}{l}\text { Pay benefit to beneficiaries } \\
\text { who meet requirements }\end{array}$ & & \\
\hline $\begin{array}{l}\text { Macroeconomic } \\
\text { effects: Trade }\end{array}$ & -- & -- & $\begin{array}{l}\text { Some firms see increased } \\
\text { business opportunities, while } \\
\text { others face additional competition }\end{array}$ & $\begin{array}{l}\text { Workers can see both increased and reduced } \\
\text { opportunities from competition. } \\
\text { Consumers: increased options and better } \\
\text { prices. } \\
\text { Overall, theory tends to predict overall gains to } \\
\text { trade. }\end{array}$ \\
\hline $\begin{array}{l}\text { Macroeconomic } \\
\text { effects: FDI }\end{array}$ & & & $\begin{array}{l}\text { Depending on the net effect of the } \\
\text { agreement on FDI, some firms see } \\
\text { increased business opportunities of } \\
\text { investing abroad, while others face } \\
\text { additional competition in the local } \\
\text { market. }\end{array}$ & $\begin{array}{l}\text { Workers: could see new job opportunities. } \\
\text { Consumers: increased options and lower } \\
\text { prices. } \\
\text { Overall, theory tends to predict overall "gains } \\
\text { from trade". }\end{array}$ \\
\hline $\begin{array}{l}\text { Macroeconomic } \\
\text { effects: Gross } \\
\text { National Product }\end{array}$ & & & & $\begin{array}{l}\text { More productive opportunities for domestic } \\
\text { factors may translate in more consumption and } \\
\text { investment opportunities. }\end{array}$ \\
\hline
\end{tabular}

(Continued on next page.) 
Table 3.6. General Cost-benefit matrix (continued)

\begin{tabular}{|c|c|c|c|c|}
\hline \multirow[b]{2}{*}{ Effect group } & \multicolumn{4}{|c|}{ Benefits and costs for partner country stakeholders } \\
\hline & Expats & $\begin{array}{l}\text { Social security } \\
\text { agency }\end{array}$ & $\begin{array}{l}\text { Firms that employ expats } \\
\text { to U.S. }\end{array}$ & $\begin{array}{l}\text { Partner country } \\
\text { economy and population } \\
\text { at large }\end{array}$ \\
\hline $\begin{array}{l}\text { Impacts from added- } \\
\text { worker effect }\end{array}$ & $\begin{array}{l}\text { The income of foreign "induced expats" } \\
\text { increases between } 0 \text { and the amount of the } \\
\text { increase for "always taker" expats (shared with } \\
\text { firm) }\end{array}$ & -- & $\begin{array}{l}\text { Reduce costs for firms from the } \\
\text { workers they decide to send (share } \\
\text { with expat) }\end{array}$ & -- \\
\hline $\begin{array}{l}\text { Impacts from the } \\
\text { benefit provision }\end{array}$ & $\begin{array}{l}\text { Some become able to receive benefits by } \\
\text { combining qualifying quarters to surpass the } \\
\text { local laws minimum required years of } \\
\text { contribution }\end{array}$ & $\begin{array}{l}\text { Pay benefit to beneficiaries } \\
\text { who meet requirements }\end{array}$ & & \\
\hline $\begin{array}{l}\text { Macroeconomic } \\
\text { effects: Trade }\end{array}$ & -- & -- & $\begin{array}{l}\text { Some firms see increased business } \\
\text { opportunities, while others face } \\
\text { additional competition }\end{array}$ & $\begin{array}{l}\text { Workers can see both increased } \\
\text { and reduced opportunities from } \\
\text { competition. } \\
\text { Consumers: increased options } \\
\text { and lower prices. } \\
\\
\text { Overall, theory tends to predict } \\
\text { overall gains to trade. }\end{array}$ \\
\hline $\begin{array}{l}\text { Macroeconomic } \\
\text { effects: FDI }\end{array}$ & & & $\begin{array}{l}\text { Some firms see increased business } \\
\text { opportunities, while others face } \\
\text { additional competition }\end{array}$ & $\begin{array}{l}\text { Workers: could see new job } \\
\text { opportunities. } \\
\text { Consumers: increased options } \\
\text { and lower prices. } \\
\text { Overall, theory tends to predict } \\
\text { overall "gains from trade". }\end{array}$ \\
\hline $\begin{array}{l}\text { Macroeconomic } \\
\text { effects: Gross National } \\
\text { Product }\end{array}$ & & & & $\begin{array}{l}\text { More productive opportunities for } \\
\text { foreign factors translate in more } \\
\text { consumption and investment } \\
\text { opportunities. }\end{array}$ \\
\hline
\end{tabular}


This framework facilitates an objective perspective on the potential favorable and unfavorable effects of signing totalization agreements with countries of different characteristics, and evaluating how the partner country's characteristics affect different stakeholders. The totalization agreement literature is still in its infancy and, thus, there is still a large amount of uncertainty about the values of the costs and benefits. Those interested in doing prospective analyses using this framework may face more or less challenges finding the appropriate data and estimates depending on the country in question. But the framework may help analysts and policymakers in evaluating possible totalization agreements and thinking through all of the likely impacts.

This framework entails a piece-wise quantification of the effects for each cell component in Table 3.6. We will perform an exercise quantifying some of these effects for two categories of countries, developed and developing economies. The framework will allow for sensitivity analyses to account for uncertainty surrounding the quantified effects and by partner country's characteristics. This exercise will also be illustrative of how the framework can be used to analyze potential treaties with new partner countries.

\section{Filling in the Framework: Valuation of costs and benefits}

In the previous chapter, we discussed the benefits and costs that could emerge from the different effects of the totalization agreements. In this chapter, we discuss their valuation.

In order to assess the values for each matrix cell, we make use of data or rely on theory when the appropriate data is not available. Hence, we analyze what economic theory predicts, what existing economic research on totalization agreements predicts, 
what we can interpolate from research in other economic domains, and what remains unknown (the research gaps).

We discuss the extent to which some of these values can be estimated, or approximated, with existing evidence, as well as when it is not yet possible to do that. The latter will identify gaps that could be filled with further research. We rely on results from the two prior studies (Seshadri 2019 and Prados et al. 2019) that include estimates of impacts on trade and macroeconomic variables. A key piece missing from existing research is an analysis of the totalization agreements' effects on workers' decisions and welfare. For this, we produce an original, stylized life-cycle model to evaluate the welfare effects of being relocated abroad as a function of some of the agreement characteristics.

We use data from the U.S. and foreign CoC; tax-filing data from the Internal Revenue Service; data on certain types of nonimmigrant visas, by nationality, issued by the U.S. Department of State; and data on social security benefits paid.

We follow the structure of Chapter 3 in terms of the discussion of groups of costs and benefits.

\subsection{Calculating effects on and responses of workers with a microeconomic model}

As discussed in Chapter 3, totalization agreements have several direct effects on individual workers, but workers and firms can also change their behavior as a result of the totalization agreement's, introduction which may amplify or reduce the direct effects. Depending on workers' and firms' responses, there may be consequences for payroll and income tax receipt and social security benefits paid. While many first-order effects can be calculated by relatively simple means, calculating effects resulting from 
behavioral changes requires a model for individual worker behavior, preferably a lifecycle model along the lines of, for example, Fonseca et al. (2020), French (2005), Gustman and Steinmeier (2009), and Scholz et al. (2006), augmented with totalization agreements' provisions of and other relevant aspects. This can then be combined with a macroeconomic model of aggregate firm behavior, for example, the one in Prados et al. (2019). Building a realistic individual model as rich as the ones in the cited sources is outside this study's scope, but for illustrative purposes, we develop a simplified life-cycle model that allows us to compute some hypothetical scenarios. Appendix I contains a description of the model. It should be emphasized that, because this model omits many relevant aspects, ${ }^{9}$ these are not realistic predictions but illustrations of the kind of computations one could do with a more realistic model. In the following, we present some model calculations to supplement more direct calculations of first-order effects.

\subsection{Valuing the impacts of totalization agreements through the effects on always-taker expatriate workers}

We start by tackling the most direct effects of totalization agreements, those that accrue to the firms and workers who would be affected even absent any effects on behaviors.

These benefits are those that accrue to U.S. workers, the "always takers" sent by their American employer to work in the partner country and who would do so regardless of whether there is a signed totalization agreement or not. Accounting for the benefit for this matrix cell requires an estimation of the magnitude of the benefit per worker as well

\footnotetext{
${ }^{9}$ Some key limitations are that there is no uncertainty in the model and there are no borrowing constraints aside from a single, lifetime budget constraint.
} 
as an estimate of the number of affected individuals. An approximation of this cell's total value for could be expressed as $N A \times T A$, where $N A$ is the number of American always takers sent to the partner country, and TA is the average benefit — or shadow price per worker (regardless of how that benefit is distributed between employer and employee).

Estimating NA, the number of "always takers," is straightforward conceptually for prospective cost-benefit analyses, as it equals the number of expatriates who, under the status quo, pay taxes to both nations. For retrospective analyses of countries with recently signed agreements, it can be approximated by the number of expatriates subject to double contribution in the years prior to the agreement. For agreements signed a long time ago, however, the number of expatriates before the agreement may not present a reasonable approximation as the economies may have changed substantially. Hence, it may be preferable to approximate it by using the number of individuals with a certificate of coverage ( $\mathrm{CoC})$, then multiply it by one minus the inverse of the totalization agreement's expected impact on expat flows. This is discussed in the next subsection, but for now we take this number to be approximately 0.8 , for illustrative purposes.

As discussed in Chapter 3, the benefit per individual for always takers amounts to the taxes they save from avoiding the double taxation. To illustrate our calculations, consider the following example. Suppose that the partner country's social security tax rate is $20 \%$, half of which is payable by the employee and half by the firm, and that the expat has an income equivalent to USD $\$ 100,000$. Absent a totalization agreement, she 
would have to pay $\$ 10,000$ to the partner country's social security administration in addition to the amount she owes to the SSA.

More generally, an individual $i$ with income $Y_{i}$, and paying foreign social security tax rate $r$ would benefit directly by $Y_{i} \times r$. The firm that employs her - which is, absent a totalization agreement, subject to an employer contribution to the partner country social security — would also benefit by the expatriate worker's income multiplied by the host country's applicable tax rate. The tax rate payable by the employer, $r^{f}$, may be different from $r$. The amount payable by the firm can be summarized by the expression $Y_{i} \times r^{f}$. The combined direct benefit for the firm and the employee is $T A_{i}=Y_{i} \times\left(r+r^{f}\right)$.

Most employers compensate their workers for their additional tax burden, if any (KPMG International 2019, p. 80). Thus, absent a totalization agreement, most employers would have compensated the worker's wage so that her take-home pay was the same as before moving. In this case, the employee would have had a zero direct benefit from the totalization, but the total benefit $T A_{i}$, would be even larger, as the employer would have had to pay an overpayment, $\Delta, \mathrm{s}$ so that the take-home for the employee remains the same. The total benefit $T A_{i}$ then equals $(1+\Delta) \times Y_{i} \times\left(r+r^{f}\right)$, where $\Delta=r /(1-r){ }^{10}$

\footnotetext{
${ }^{10}$ Note that countries commonly use a "wage-ceiling" to determine social security contribution liabilities, which implies that the tax rate is imposed only to income below the ceiling. To the extent that a wage ceiling applies, the benefit would be applicable to the minimum of $(1+\Delta) \times$ $Y_{i}$ and the wage ceiling.
} 
Table 4.1 A stylized example of valuing benefits for the case of the totalization agreement with Germany and Chile for always takers (and cost for the partner country social security agency)

\begin{tabular}{|l|l|l|l|l|l|l|}
\hline & $\begin{array}{l}\boldsymbol{r}^{\mathbf{a}} \\
\text { Employee } \\
\text { rate }\end{array}$ & $\begin{array}{l}\boldsymbol{r}^{\boldsymbol{f}} \\
\text { Employer } \\
\text { rate }\end{array}$ & $\boldsymbol{Y}_{\boldsymbol{i}}{ }^{\boldsymbol{b}}$ & $\mathbf{T A}_{\boldsymbol{i}}$ & $\mathbf{N A}^{\mathbf{c}}$ & $\begin{array}{l}\text { Total } \\
\text { direct } \\
\text { benefit } \\
\text { (in USD } \\
\text { millions ) }\end{array}$ \\
\hline Germany & $9.3 \%$ & $9.3 \%$ & 98,175 & 22,433 & 8,164 & $183.1 \mathrm{M}$ \\
\hline Chile & $\begin{array}{l}13.54 \% \text { (total employer } \\
\text { +employee) }\end{array}$ & 36,000 & 4,875 & 816 & $3.98 \mathrm{M}$ \\
\hline
\end{tabular}

Notes: ${ }^{a}$ Source: ILO (2017) and SSA (2018c). The figure for Chile corresponds to the mandatory individual account program which applies to workers joined the workforce after 1983. b The average income among CoC holders for Germany is more than $\$ 200,000$ but the "wage ceiling" in Germany is EUR 82,500 according to PWC Worldwide Tax Summaries, reviewed on July 09, 2020, https://taxsummaries.pwc.com/germany/individual. This amounts to USD 98,175 at the 1.19 EUR to USD exchange rate valid on Aug 14, 2020 (Morningstar). For Chile, the wage ceiling is 908.4 Unidades de Fomento (IFs), which corresponded to about $\$ 36,000$ USD as of 2017: ' This was calculated by multiplying the inverse of the expected effect of TAs on expat flows $\sim 0.8$ (see next subsection) times the number of $\mathrm{CoC}$ for Germany and Chile (see next subsection).

Table 4.1 presents an example of a retrospective calculation of the total direct benefit for firms and workers accrued through the always takers effects. These are all expressed at the yearly level. The example uses numbers and estimates for Germany, where the rate equals approximately $9.3 \%$ levied on the worker and $9.3 \%$ levied on the firm, so both $r$ and $r^{f}$ equal $9.3 \%$ (SSA 2018b). Though the average yearly income among expatriates to Germany is much higher than that, social security taxes are only levied upon the first EUR 82,500 or almost USD 100,000 per current (2020) exchange 
rates. ${ }^{11}$ In this case though even if employers were providing over-payment to compensate for the foreign taxes, the benefit would still be calculated from income topped at the $\$ 98,175$ level, which is multiplied by the $18.6 \%$ total tax rate to obtain $T A_{i}$. We estimate there to be about 10,220 expatriates currently enjoying the benefit. Assuming about $80 \%$ of them are always takers, that would give a total benefit $T A$ of about $\$ 183$ million.

For those interested in estimating this value for a prospective cost-benefit analysis for a country without a signed totalization agreement, the main figures to obtain or proxy are the following: 1) the social security tax rate in the candidate country as it applies to both the employee and the employer; 2) the wage ceiling of American expatriate managers' likely wages in that country. Per the numbers reported in Prados et al. (2019), American expatriates' wages tend to be higher than the wage ceilings for most countries, therefore, the candidate country's wage ceiling may be used if there is one. The average earnings for the median expatriate workers in other developed countries in 2017 was $\$ 158,429$ and the corresponding figure for the average worker was $\$ 307,557 .{ }^{12}$ However, it was lower for the six countries with relatively lower GDP per capita, where the corresponding figures were $\$ 99,414$ and $\$ 150,850$ respectively. ${ }^{13}$

\footnotetext{
11 The wage ceiling in 2019 was EUR 82,500 according to PWC Worldwide Tax Summaries, reviewed on July 09,2020, https://taxsummaries.pwc.com/germany/individual. This amounts to USD 98,175 at the 1.19 EUR to USD exchange rate valid on Aug 14, 2020 (Morningstar).

${ }^{12}$ We calculated this as the average (not weighted by population) of the mean and median Medicare earnings for the following countries: Denmark, France, Netherlands, Finland, Greece, South Korea, Japan, Italy, Canada, Austria, Germany, United Kingdom, Switzerland, Australia, Luxembourg, Ireland, Belgium, Norway, Portugal, and Sweden. The data was provided by the Social Security Administration.

${ }^{13}$ The average was taken for the following countries: Chile, Czech Republic, Greece, Hungary, and Slovakia.
} 
One of these numbers could be used, depending on the characteristics of the candidate country. The last required figure is the likely number of always takers. One possible source for this is the number of individuals who in the most recent year used the foreign income tax deduction from that country in their tax returns, which is available from the Internal Revenue Service (IRS).

These calculations do not consider that other taxes, such as income tax, need to be paid for the additional income (increasing the totalization agreement's effect), and that the higher earnings, if below the SSA wage ceiling, would lead to higher Social Security benefits later on. In the subsection below, we discuss how these effects can be valued, and the extent to which they can or cannot be important for overall cost-benefit calculations.

\subsubsection{Measuring indirect effects arising from over-compensation (1+ 1$)$}

So far, we have not had to account for the magnitude of $\Delta$, because in the cases studied, $Y$ surpasses the wage ceiling and, hence, the quantity $(1+\Delta) \times Y_{i}$ has not translated into a different $T A$ number. However, there are other indirect benefits and costs that can arise, and may or may not be of quantitative importance when $\Delta>0$.

Note that here we are discussing only the compensation for social security tax rates, though firms may provide additional compensation for moving costs, children's schooling, or any other compensation that firms may provide to expatriates. These other compensation forms would not be affected by totalization agreements and, hence, there is no need to consider them here.

In particular, consider the case of a firm compensating their employees going to nontreaty countries with $\Delta=r /(1-r)$. These workers, in addition to paying the partner 
country's social security payroll taxes, also have to pay regular income taxes. Denote the average income tax rate in the partner country for someone with the income level $Y_{i}$ with $\mathrm{\tau}$. The expatriate worker then pays income taxes in the amount of $\mathrm{T} \times(1+\Delta) \times Y_{\text {i }}$. This uses the simplifying assumption that there is a flat tax rate, whereas in reality, income tax schedules are more complex, but this simplification is useful for the purposes of this discussion. ${ }^{14}$ Now assume the country signs a totalization agreement with the U.S., and as a result, the firm reduces the compensation to $Y_{i}$. In this case, the income taxes paid to the partner country are only $\tau \times Y_{i}$. This represents a benefit to the firm/expatriate employee of $\mathrm{T} \times \Delta \times Y_{i}$, and a cost to the partner country's government of the same amount.

Consider the numbers used above for Germany in Table 4.1. We have NA = 8,164 always takers expatriate workers to Germany. U.S. firms would have to overcompensate with a $\Delta=0.0925 /(1-0.0925)=10.2 \%$. Since the compensation only needs to be done for the portion of income subject to social security contributions, we use $Y_{i}=98,175$. Hence, the total benefit from this effect would equal $0.102 \times 98,175 \times \mathrm{T}$. Given the high income of expatriate workers, $\mathrm{T}$ is better approximated by the top income tax rate instead of the average income rate, though in practice the average income tax rate will be slightly lower than that. Using the rates as reported by PWC tax

\footnotetext{
${ }^{14}$ Also, the U.S. has worldwide taxation of its citizens, so this assumes that foreign taxes are higher than U.S. taxes and can be fully deducted, such that the individual does not pay U.S. income taxes. Our micromodel does allow for progressivity in income tax, but makes the simplifying assumption that the combined partner country and U.S. income tax is the same as U.S. income tax would be for the same income had the individual lived and worked in the U.S.
} 
summaries,,$^{15}$ we calculate $\mathrm{T}$ to equal 0.3056 . Hence, the benefit to the U.S. worker/firm from this concept would equal $\$ 3,104$, a small but non-negligible fraction of the benefit of $\$ 22,433$ calculated above. By multiplying it by $N A$, this results in an additional $\$ 25.3$ million to add to the cell of benefits accrued to the domestic workers/firms (see Table 4.2 below).

Table 4.2 Additional benefits to U.S. always takers and their employers arising from a reduction in income taxes from the drop in $\Delta$

\begin{tabular}{|l|l|l|l|l|l|}
\hline Country & $\mathbf{T}^{\mathbf{a}}$ & $\mathbf{Y}_{i}{ }^{\mathbf{b}}$ & $\boldsymbol{\Delta}$ & $\mathbf{N A}$ & $\begin{array}{l}\text { Total direct } \\
\text { benefit (in USD } \\
\text { millions) }\end{array}$ \\
\hline Germany & 0.31 & 98,175 & 0.102 & 8,164 & 25.3 \\
\hline Chile & 0.355 & 36,000 & 0.12 & 816 & 1.25 \\
\hline
\end{tabular}

Note: ${ }^{a}$ We use the average (Medicare) earnings (data from SSA) of American expatriates and the income tax schedules for individuals in Germany to calculate it. For Chile, we use $35.5 \%$, which is the marginal income tax rate for all income above 8,000. Expatriates to Chile have average earnings of $235,000 .{ }^{\mathrm{b}}$ We use the wage ceiling applicable in Germany and Chile, respectively.

Note that, as is the case for the benefit logged in Table 4.1, this benefit has its mirror image and should be logged as a negative for the partner country, though in this case the revenue loss does not accrue to the social security agency but to the public sector income in general.

Similar calculations can be made for the partner country's expatriates coming into the U.S. The numbers for those flows in the case of Germany are similar. The

\footnotetext{
${ }^{15} \mathrm{https}$ ://taxsummaries.pwc.com/germany/individual. To calculate this, we use the average (Medicare) earnings (data from SSA) of American expatriates to Germany in 2017 which was $\$ 209,398.70$, rather than the wage ceiling since this does not apply to income taxes. We use the tax rate schedule for individual filers.
} 
description of those estimates is presented later in the text. But as an advance, we calculate the number of always takers from Germany to be 9,300 , and the reported benefit to them, and the federal government's cost from foregone revenue to be of $\$ 23.9 \mathrm{M}$.

When the expatriate flows to and from the U.S. and the partner country are of about the same magnitude, and expatriate wages of the are also about the same level (as is the case in the numbers for Germany shown earlier), these costs and benefits will be similar and, thus, largely cancel out in aggregate for each country's stakeholders. However, this calculation will be affected by the different tax rates, which explains the relatively larger benefit for German stakeholders shown in these calculations. On the other hand, in cases where more workers are sent abroad than come in, and with larger earnings of the domestic over the partner country expatriates, as is the case with Chile, the totalization agreements will provide a higher benefit for the domestic firms and workers, and higher costs for the partner country's public sector income, which will suffer from the foregone revenue.

\subsubsection{Allowing for behavioral effects among always takers}

The always takers do not have a behavioral response in the sense that these workers would be going on a foreign assignment whether or not there is a totalization agreement. However, as explained above, other potential responses do not depend on whether there is a totalization agreement. These responses start with additional pay for the employees to compensate them for the additional costs, which differ in the two regimes. The worker can then decide to spend the additional income in the period abroad, or save (part of) it and spend it later. If the worker earns below the Social 
Security maximum taxable income, the additional earnings also induce additional benefits after retirement.

To illustrate the types of calculations involved in accounting for these additional pathways, we computed some scenarios using the microeconomic model introduced in section 4.1. According to BGRS (2016, p. 50), the largest group of employees on foreign assignments is age $40-49$, and as mentioned earlier, the earnings of U.S.-based workers sent abroad tend to be high. Therefore, in our computations, we consider a college graduate sent to Germany or Chile for a five-year assignment starting at age 45 , who in the U.S. would earn $\$ 209,398.70$ (the mean earnings on CofC for assignments in Germany) or $\$ 232,176.04$ (the mean earnings on CofC for assignments in Chile), respectively, at age 45 .

Warneke and Schneider (2011) find that expatriates' preferences for compensation packages are very heterogeneous in Germany and Spain, and there is also large variation in satisfaction with compensation packages (Suutari and Tornikoski 2011), despite these packages tending to be very expensive for the employers (e.g., Bonache and Zárraga-Oberty 2017). From this literature, we do not obtain specific guidance about the disutility of being sent abroad that can be used in our model, and therefore, we perform our calculations for a few such values - no disutility, disutility corresponding with a $20 \%$ drop of consumption, and disutility corresponding with a $50 \%$ drop of consumption.

We then compute lifetime utility if the employee would stay in the U.S., and subsequently find the smallest value of $\delta$ (additional gross earnings relative to staying in the U.S.) such that the individual would weakly prefer the foreign assignment (i.e., 
results in the same lifetime utility), both with and without a totalization agreement. We then compute the resulting employer cost.

Our calculations do not account for various employer costs unrelated to earnings or taxes paid, such as travel and moving cost reimbursements and housing allowances. We assume that these are the same with or without a totalization agreement, and play no role in the cost-benefit analysis.

Table 4.3 shows the results of this exercise. There were no effects on retirement age, which was 70 in all cases. This corresponds well with what we know about highincome high-educated individuals, who retire later. The foreign assignment costs increase rapidly with the disutility of working abroad and the need for employer compensation for this. However, this increase is similar with and without totalization agreement, so cost reductions due to the agreement are much less sensitive to this unknown parameter. The effects of the agreement are much larger in Germany than in Chile, due to the much higher wage ceiling in Germany. 
Table 4.3: A stylized example of calculating employer costs (per employee) for the case of the totalization agreements with Germany and Chile for always takers (TA versus no TA) and induced workers (TA versus U.S.), with employer compensation such that the worker is equally well off

\begin{tabular}{|l|l|l|l|}
\hline $\begin{array}{l}\text { Partner country and } \\
\text { cost comparison }\end{array}$ & \multicolumn{3}{|l|}{$\begin{array}{l}\text { Disutility of foreign assignment } \\
\text { (\% of consumption) }\end{array}$} \\
\hline & $\mathbf{0}$ & $\mathbf{2 0}$ & $\mathbf{5 0}$ \\
\hline Germany & & & \\
\hline Cost at age 45, U.S. & $217,936.10$ & $217,936.10$ & $217,936.10$ \\
\hline Cost at age 45, no TA & $241,067.61$ & $275,792.73$ & $369,261.05$ \\
\hline Cost at age 45, TA & $217,936.10$ & $252,571.75$ & $346,036.88$ \\
\hline & & & \\
\hline noTA - U.S. & $23,131.51$ & $57,856.63$ & $151,324.95$ \\
\hline TA - U.S. & 0 & $34,635.65$ & $128,100.78$ \\
\hline TA - no TA & $-23,131.51$ & $-23,220.98$ & $-23,224.17$ \\
\hline & & & \\
\hline Chile & & & \\
\hline Cost at age 45, U.S. & $240,713.44$ & $240,713.44$ & $240,713.44$ \\
\hline Cost at age 45, no TA & $248,244.49$ & $286,280.96$ & $388,658.64$ \\
\hline Cost at age 45, TA & $240,713.44$ & $278,751.68$ & $381,127.58$ \\
\hline & & & \\
\hline noTA - U.S. & $7,531.05$ & $45,567.52$ & $147,945.20$ \\
\hline TA - U.S. & 0 & $38,038.24$ & $140,414.14$ \\
\hline TA - no TA & $-7,531.05$ & $-7,529.28$ & $-7,531.06$ \\
\hline
\end{tabular}

Note. U.S. = always working in the U.S. TA $=$ foreign assignment with totalization agreement; no TA = foreign assignment without totalization agreement

Note that the totalization agreement's implied benefits for always takers in this model (see the rows "TA - no TA") are similar to the figures reported in Table 4.1 (see column $Y_{i}$ ). When assuming no disutility of foreign assignment, the Table 4.1 estimate of $\$ 22,431$ is very close to the model estimate of $\$ 23,132$; while the estimate for Chile, $\$ 4,875$, is lower than the $\$ 7,531$ from the model.

From these estimates, we learned a number of important lessons which have practical implications for conducting totalization agreements cost-benefit analyses beyond Chile and Germany: 
1. The always takers' implied benefit from the estimation of the micromodel is remarkably similar to the more naïve calculations presented in Table 4.1. This is encouraging for anyone using this framework to conduct an analysis and who is unable to estimate a micromodel such as this one. This would be the case, for example, for someone conducting a prospective cost-benefit analysis.

2. As in 1, the fact that the estimated retirement age did not change in the specifications, shows that using the simple calculations above can provide a good approximation to actual benefits

3. Allowing for foreign assignment disutility affects the benefit computation, but the results are not dramatically affected. The estimates with disutility are within $5 \%$ of the estimates without disutility. This again shows the robustness of the microestimates and the estimates from Table 4.1

4.2.3 Valuing the Impacts on the finances of Social Security agencies in home and partner countries

Totalization agreements allow some expatriate workers to avoid paying taxes to two social security administrations. This implies that totalization agreements reduce some of the contributions that the agencies would otherwise receive from these workers. As shown in in the second row (red) in Table 4.4 below (a summary of Table 2.1), the Social Security Administration loses the taxes paid by the always takers foreign expatriates in the U.S. 
Table 4.4: Social Security taxes: Effects of a Totalization agreement. Stylized case based on the agreements with Germany

\begin{tabular}{|l|l|l|}
\hline Type of worker & Without TA & With TA \\
\hline $\begin{array}{l}\text { Americans working abroad } \\
\text { temporarily (<5 years) for U.S. } \\
\text { firm and self-employed } \\
\text { (temporarily) }\end{array}$ & $\begin{array}{l}\text { Pay OASDI taxes } \\
\text { Pay foreign taxes }\end{array}$ & $\begin{array}{l}\text { Pay OASDI taxes } \\
\text { Do not pay foreign taxes }\end{array}$ \\
$\begin{array}{l}\text { Foreign nationals working } \\
\text { temporarily in the U.S. }\end{array}$ & Pay OASDI taxes & Do not pay OASDI taxes \\
\hline
\end{tabular}

The calculation for the amount lost is similar to the one done in section 4.1.1 above. The social security tax rate $r$ equals 6.2 and is the same as that levied on the employer, so that $r+r^{f}=12.4$.

The income on which the taxes are levied, $(1+\Delta) Y_{i}$ in this case, equals the income for the foreign always taker expat, up to the wage ceiling in the U.S., which in 2020 equaled $\$ 137,700$. We do not have data on the earnings of German expatriates with certificates in the U.S. Given that Germany has a similar level of economic development as the U.S., and that the earnings of American expatriates in Germany by far exceed the wage ceilings of both countries, it is reasonable to assume that the earnings of the German expatriates will be close to or exceed the wage ceiling of the U.S. Hence, we take $(1+\Delta) Y_{i}$ to equal $\$ 137,700$.

Using data from SSA, Prados et al. (2019) report an average of 2,325 foreign certificates issued annually in Germany. If workers stay an average of five years that would imply an average of 11,625 German expatriates in any given year. If as above, we assume that the always takers represent about $80 \%$ of the German expatriates in the U.S., that would mean that 9,300 Germans would have contributed to the Social Security Administration's OASDI trust funds.

These numbers are shown in table form in Table 4.5. 
Table 4.5: A stylized example of valuing the financial costs to the SSA from the foregone revenue from the always taker partner-country expatriates, which is also the benefit to always taker partner country expatriates

\begin{tabular}{|l|l|l|l|l|l|l|}
\hline Country & $\begin{array}{l}\boldsymbol{r} \\
\text { Employee } \\
\text { rate } \\
\text { applicable } \\
\text { in U.S. }\end{array}$ & $\begin{array}{l}\boldsymbol{r}^{\boldsymbol{f}} \\
\text { Employer } \\
\text { rate } \\
\text { applicable } \\
\text { in U.S. }\end{array}$ & $\boldsymbol{Y}^{\boldsymbol{a}}$ & $\mathbf{T A}_{\boldsymbol{i}}$ & $\mathbf{N A}^{\mathbf{b}}$ & $\begin{array}{l}\text { Total direct } \\
\text { benefit/cost } \\
\text { (in USD } \\
\text { millions) }\end{array}$ \\
\hline Germany & $6.2 \%$ & $6.2^{*}$ & 137,700 & 17,075 & $0.8^{*} 11,625=9,300$ & $158.8 \mathrm{M}$ \\
\hline Chile & $6.2 \%$ & $6.2^{*}$ & 137,700 & 17,075 & N/A & N/A \\
\hline
\end{tabular}

Notes: a This is the wage ceiling applicable in the U.S. in $2020 .{ }^{\mathrm{b}}$ This was calculated by multiplying the inverse of the expected effect of TAs on expat flows $\sim 0.8$ (see next section) times the number of foreign $\mathrm{CoC}$ for Germany from the U.S.

As discussed above, the existence of employer compensation for social security taxes can imply a further benefit for always taker expatriates from reduced income tax liability and a mirror cost for the other country's pubic finance. Below, we conduct the comparable calculation for the partner country's benefit for this concept, which is also a cost for the U.S. in terms of foregone revenue. The calculations in Table 4.6 show that for Germany, expatriates and their employers benefit from an additional 23.9M of foregone revenue to the IRS. 
Table 4.6: Additional benefits to partner-country Always takers and their employers arising from a reduction in income taxes from the drop in $\Delta$

\begin{tabular}{|l|l|l|l|l|l|}
\hline Country & $\mathbf{T}^{\mathbf{a}}$ & $\mathbf{Y}_{i}^{\mathbf{b}}$ & $\boldsymbol{\Delta}$ & $\mathbf{N A}$ & $\begin{array}{l}\text { Total direct } \\
\text { benefit (in USD } \\
\text { millions) }\end{array}$ \\
\hline Germany & 0.17 & 137,700 & 0.11 & 9,300 & 23.9 \\
\hline Chile & 0.18 & 137,700 & 0.11 & N/A & N/A \\
\hline
\end{tabular}

Note: ${ }^{a}$ We use the single filer income tax rate schedule for federal income tax rates in the U.S. and a standard deduction of $\$ 12,200$; average (Medicare) earnings (data from SSA) of American expatriates to Germany and Chile who have average earnings of 209,399 and 235,000, respectively. ${ }^{\mathrm{b}}$ We use the wage ceiling applicable in the U.S. in 2020.

4.2.4 Revenue loss for U.S. governments from the additional compensation, which is also the additional benefit to partner-country "always taker" expatriates

Suppose we are interested in analyzing the SSA's revenue loss from a prospective totalization agreement with a potential candidate country. One needs two pieces of data: 1) the number of individuals from that country who would be sent to the U.S., and 2) the expatriates' average earnings.

While in this case data from certificates of coverage do not exist, we could approximate the number with the number of individuals with short-term work visas (E-1, E-2, H1-B, H1-B1, H2-D, L-1 and L-2) from that country. This number can be obtained from the U.S. Department of State. However, this may be better viewed as an upper bound since some in those visas may have been hired by an American employer, stay longer than five years, or may otherwise not be covered by the totalization agreement.

For the average earnings, one may use the wage ceiling as managers tend to have earnings that surpassed it, as we have discussed.

The income lost for the partner country's social security agency is the mirror image of the benefit accrued to the home country's always workers and their employers. 
As described above (see Table 4.1) in the example calculation for Germany, this would imply a revenue loss of $\$ 183.1$ million.

4.3 Valuing the Impacts of totalization agreements through the added expatriate worker effect

In this section, we discuss how one could estimate the value of the direct benefits accrued through American workers "induced" to being sent abroad by their employers, and foreign workers being sent here by their own employers.

As above, accounting for this benefit requires an estimate of the magnitude of the workers' benefits as well as an estimate of the agreement's impact on the number of increased worker flow. An approximation of the total value for this matrix cell could be expressed as $\mathrm{Nl} \times \mathrm{TI}$, where $\mathrm{NI}$ is the total number of workers induced to work in the partner country, and $\mathrm{TI}$ is the average benefit, or shadow price, per induced worker. 4.3.1 Estimates of totalization agreement's impact on worker flows: the number of "induced" workers

Before delving into our benefit estimate, we note that there is little evidence of an agreement's effect on these flows. Prados et al. (2019) find no clear pattern on employment of multi, neither for American nor foreign firms, though we acknowledge that, due to sample size, meaningful impacts cannot be ruled out. The reason for this lack of effect may be noisy estimates derived from relatively small sample sizes. (The sample is limited to the number of countries that have signed an agreement.)

Absent a good estimate of this effect, one option is to use a lower and an upper bound and assess whether that affects the overall direction of the cost-benefit analysis. The lower bound could be zero given that the prior empirical study was unable to 
establish statistically significant effects. For an upper-bound, an option could be to use the proportion of post- to pre-levels of employment flows after a totalization agreement. Among the individual country cases analyzed in Prados et al. (2019), Poland had the largest increase in workers claiming the foreign-earned income exclusion around the years of the totalization agreement's signing, though the data is missing for some years. Even in this case, one can bound the increase to no more than 40,000 , which would represent an increase of about $40 \% .^{16}$

We include the lack of knowledge of this number as an important research gap

\section{in the literature.}

\subsubsection{Estimating the benefit for the "induced" worker}

As described in the previous chapter, valuing the benefit for employees who become expatriates due to the totalization agreement is more challenging, as the benefit to them lies somewhere between 0 and the value for the always takers.

Our micromodel is of some use here, but with some limitations. Our previous calculations with the model assumed that the employer exactly compensates the worker for the loss of (lifetime) utility. Hence, the worker is indifferent about being sent abroad or not and does not gain from the totalization agreement. Instead, the benefits of the agreement are for the employer. For the employers of the always takers, the benefits are necessarily positive, and Table 4.7 gives some tentative estimates of these. The table also shows the cost differences that are relevant for the induced workers. These

\footnotetext{
${ }^{16}$ While the number of employees of American affiliates who filed for the foreign-earned income inclusion was significantly higher in the first year after the totalization agreement, it is notable that there was an increasing trend both before and after the signing. This strengthens the idea that this number should be taken as an upper-bound rather than an estimate of the number.
} 
would (by definition) stay in the U.S. without a totalization agreement, but work in the partner country with the agreement. With the compensation necessary, this implies additional costs to the employer under a TA, for example, $\$ 34,636$ if the worker's disutility of foreign assignment in Germany is equal to a $20 \%$ drop in consumption. For induced workers, this implies that the worker's additional productivity for the firm must be higher than $\$ 34,636$, because otherwise, it would be more profitable for the firm to keep the worker in the U.S. In the absence of a totalization agreement, the additional cost for this worker in Germany, relative to the U.S., would be $\$ 57,857$. Because by the definition of an induced worker, the worker would not be sent to Germany in the absence of a totalization agreement, the additional productivity of the worker for the firm must be lower than $\$ 57,857$. Thus, we have a lower and an upper bound of the additional productivity of the worker in Germany. The additional firm costs under the totalization agreement are $\$ 34,636$. The net benefit of the agreement for the firm is equal to the additional productivity minus the additional cost. Given the bounds on the former, we conclude that this is bounded by $\$ 34,636-\$ 34,636=\$ 0$ and $\$ 57,857$ $\$ 34,636=\$ 23,221$, which is the benefit for an always taker. So, this again affirms that the benefits for an induced worker are bounded by $\$ 0$ and the benefits for an always taker. To obtain a more precise estimate, we need more information about the productivity of the worker in the U.S. and in Germany. This is outside the model's purview and requires external information.

While not entirely satisfactory, having bounds in some of these parameters may be useful to draw conclusions from cost-benefit analysis as long as the bounds are small relative to the gap between the rest of the benefits and the costs. 
Table 4.7. Bounds for the benefit estimates for induced workers in Germany and Chile

\begin{tabular}{|c|c|c|c|}
\hline & Lower Bound & Mid-point & Higher Bound \\
\hline \multicolumn{4}{|l|}{ Germany } \\
\hline Per induced worker & 0 & $\$ 11,610$ & $\$ 23,221$ \\
\hline $\begin{array}{l}\text { Total benefit } \\
\text { (assuming } 20 \% \text { of expatriates are } \\
\text { induced workers) }\end{array}$ & 0 & $\$ 27.0 \mathrm{M}$ & $\$ 54.0 \mathrm{M}$ \\
\hline \multicolumn{4}{|l|}{ Chile } \\
\hline Per induced worker & 0 & $\$ 3,765$ & $\$ 7,531$ \\
\hline $\begin{array}{l}\text { Total benefit } \\
\text { (assuming } 20 \% \text { of expatriates are } \\
\text { induced workers) }\end{array}$ & 0 & $0.78 \mathrm{M}$ & $1.54 \mathrm{M}$ \\
\hline
\end{tabular}

The model delivers more specific partial estimates if the employer offers the foreign assignment regardless of the TA, but does not necessarily compensate the worker optimally for lost utility, and allows the worker to decline the assignment. For example, suppose that the employer offers the foreign assignment with a fixed compensation of $20 \%$ of regular earnings. We can then compute lifetime utility in the U.S. (without the $20 \%$ ) and lifetime utility with the period in the partner country, with the $20 \%$, both with the totalization agreement and without. For an induced worker, we should see that the worker declines the foreign assignment in the absence of a totalization agreement but accepts it with the agreement. Hence, lifetime utility is highest with the foreign assignment and the totalization agreement, less in the U.S., and lowest with the foreign assignment but without the totalization agreement. The relevant comparison for the worker is the lifetime utility with the foreign assignment and the agreement versus a lifetime in the U.S. We can compute those utilities, but they have no easy interpretation. To interpret them, we could, for example, calculate what increase in U.S. earnings would give the worker the same lifetime utility as with the 
foreign assignment under the totalization agreement. We can then cast the totalization agreement's value to the worker in terms of an equivalent earnings increase in dollars or percentage.

We have not done these computations for several related reasons. First, this is suboptimal behavior for the firm. They would either overpay the worker or leave the opportunity to increase profits (by increasing the worker's compensation package on foreign assignment) unused. Second, the human resources literature shows that tax equalization and similar components, as well as other additional payments, are very common among multinational firms that send their employees abroad (KPMG International, 2019, p. 80), so empirically the current scenario is less relevant. Third, calculations of this sort omit the benefits of increased productivity (and hence, profits) on the firm. The bounds calculated earlier do explicitly or implicitly include these components and, therefore, are more accurate representations of what we may know about the agreement's costs and benefits, even if they do not lead to a single number. 


\subsection{Valuing the benefits and costs of the totalization provision}

The Social Security Administration keeps records on the number of totalization beneficiaries and the average benefit for each of the countries with which they maintain an agreement. Hence, valuing the cells for the cost to SSA from this concept for existing totalization agreement can be done.

The SSA's cost is approximated by multiplying the number of beneficiaries times the average monthly benefit. Table 4.8 below shows the values for the U.S. with a number of countries. In particular, it shows the average number of beneficiaries per year by host country in 2018. These numbers are published in SSA's Annual Supplemental Report. Jackson and Cash (2018) provide some detailed explanation of the formula used by SSA and partner countries to pro-rate totalization monthly benefits.

The highlighted rows show the cases for the countries used as case studies throughout the paper. There were 22,126 people receiving monthly benefits who were able to do so via the totalization agreement with Germany, across the different social security programs (retired workers, disabled workers, spouses, widow(er)s, and children). On average, the monthly benefit was $\$ 275.48$ for a total of $\$ 73.1 \mathrm{M}$ disbursed by SSA. 
Table 4.8: Valuing the benefit and costs of the "totalization" effects from totalization agreements

\begin{tabular}{|c|c|c|c|}
\hline Country & $\begin{array}{l}\text { Number of } \\
\text { beneficiaries in } 2018\end{array}$ & $\begin{array}{l}\text { Average monthly } \\
\text { benefit (in } \\
\text { USD) }\end{array}$ & \begin{tabular}{|l} 
Total (yearly) \\
implied benefit for \\
former workers and \\
cost for SSA \\
(In Millions USD)
\end{tabular} \\
\hline Australia & 5,371 & 245.34 & 15.8 \\
\hline Austria & 1,757 & 250.66 & 5.3 \\
\hline Belgium & 1,147 & 256.42 & 3.5 \\
\hline Canada & 53,342 & 237.74 & 152.2 \\
\hline Chile & 361 & 278.11 & 1.2 \\
\hline Czech Republic & 177 & 273.3 & 0.6 \\
\hline Denmark & 914 & 243.23 & 2.7 \\
\hline Finland & 507 & 262.75 & 1.6 \\
\hline France & 7,244 & 265.34 & 23.1 \\
\hline Germany & 22,126 & 275.48 & 73.1 \\
\hline Greece & 6,036 & 227.84 & 16.5 \\
\hline Hungary & 39 & 227.42 & 0.1 \\
\hline Ireland & 3,674 & 247.91 & 10.9 \\
\hline Italy & 10,179 & 225.21 & 27.5 \\
\hline Japan & 63,713 & 272.27 & 208.2 \\
\hline Luxembourg & 90 & 288.26 & 0.3 \\
\hline Netherlands & 3,710 & 247.93 & 11.0 \\
\hline Norway & 4,279 & 239.15 & 12.3 \\
\hline Poland & 15,167 & 135.4 & 24.6 \\
\hline Portugal & 2,370 & 282.51 & 8.0 \\
\hline Slovakia & 37 & 244.33 & 0.1 \\
\hline South Korea & 3,277 & 235.78 & 9.3 \\
\hline Spain & 4,159 & 233.06 & 11.6 \\
\hline Sweden & 4,384 & 222.37 & 11.7 \\
\hline Switzerland & 4,359 & 238.17 & 12.5 \\
\hline United Kingdom & 18,249 & 321.2 & 70.3 \\
\hline Total & 236,668 & 251.44 & 714.1 \\
\hline
\end{tabular}

Note. These numbers are based on Table $5 \mathrm{~m}$ from the Social Security Administration Annual Supplement Report (SSA 2018a). They include numbers from all categories: retired workers, disabled workers, spouses, widow(er)s, and children. Retired workers represent $65 \%$ of these beneficiaries overall.

As discussed in the previous chapter, this cost mirrors the benefit for the former workers, including the domestic and partner country nationals. As described in earlier chapters, Americans can also receive benefits from the partner country via totalization if 
it allows them to meet the minimum contribution period. While we do not have data to approximate partner countries' disbursements, one very rough approximation would be to assume it is symmetric, so that the same proportion and benefit amounts of partner country nationals from SSA exactly compensates the amounts Americans receive from the partner country. The numbers from Table 4.8 would also serve as the benefits estimate for American totalization beneficiaries. In that case, former American workers benefit from the totalization with Germany by $73.1 \mathrm{M}$.

For a prospective totalization agreement, obtaining precise data of the workers or former workers who could benefit by totalizing benefits could be extremely challenging or even impossible. It would require counting or estimating the number of people who have contributed to the prospective partner country but who would fall short of credits to qualify for benefits in the U.S. A more promising avenue would be to create an estimate based on the data presented above for countries with existing totalization agreements. By selecting the countries that have the closest economic similarities, and appropriately adjusting for population size and perhaps other variables, one could create an estimate that is, perhaps, close enough.

\subsection{Assessing costs and benefits form the macroeconomic impacts of totalization} agreements

Estimating the effects on trade and economy as a whole is more complex, as there are no data directly linking trade or output to totalization agreements. Hence, we need to base our estimates, or ranges of estimates, on econometric estimates or economic modeling done in prior studies. There are very few studies on totalization agreements' impacts of. Among the few is Seshadri (2019), which studies totalization 
agreements' effects on exports, imports, and Foreign Direct Investments; and Prados et al. (2019), which also studies Foreign Direct Investments and develops an international equilibrium model for worker flows and trade.

\subsubsection{Effects on trade and multinational production}

Seshadri (2019) employs a synthetic control methodology as in Abadie and Gardeazabal (2003). This essentially consists of a difference-in-differences methodology, but the control countries are replaced for a weighted average of the pool of possible controls, and the weights are chosen to maximize the similarities in trends in the "pre" period.

The study presents the following main findings. First, on average, totalization agreements lead to a reduction in exports over the five-year period following an agreement's signing of an agreement. Second, agreements also lead to an increase in imports, though this effect is small and insignificant. ${ }^{17}$ Third, the export impacts were heterogeneous across agreements, with some of the agreements raising exports, and some reducing them (though increasing them on average). With some countries, agreements have led to increases in exports; for others, they have led to increases in imports. There is not an obvious pattern linking the country's characteristics with the higher effect on exports or imports.

From the cost-benefit analysis perspective, it is useful to note that these results necessarily imply mirror images for the foreign stakeholders. The same agreements that increase exports to the partner country, increase imports from the U.S. in the partner country.

\footnotetext{
17 Seshadri (2019) also studies FDI, but we discuss that in the following subsection.
} 
Assessing the costs and benefits of trade is not straightforward, but it's important to avoid the mistake of equating exports as a positive and imports as a negative, as in mercantilist ideas. Economic models have traditionally assessed gains from trade. Increased imports may reflect benefits to consumers who enjoy the additional consumption options, and/or benefits for firms able to access additional inputs or intermediate goods in the production process.

It is difficult to assess the magnitude of the benefit arising from trade. From the perspective of the $B C$ framework, it is best to not attempt to quantify the benefits for specific firms, but rather to assign an overall "gains to trade" amount for the cell that corresponds to the column "U.S. population at large" from Table 3.6.

\subsubsection{Effects on Foreign Direct Investment}

We have two sources of findings for the effect on FDI. The microeconometric approach in Seshadri (2019) yields the finding that totalization agreements lead to an increase in FDI (that is, an outflow of investments from the U.S. to other countries).

Prados et al. (2019) assessed the likely macroeconomic impact of totalization agreements. They follow two separate approaches to study these impacts. The first consists of an analysis of the data's empirical patterns using an event study analysis of totalization agreements around their implementation dates. This event study analysis shows that for both American firms' affiliates abroad and foreign firms in the U.S., total assets increase around the agreement's implementation. Estimates from a regression analysis showed a large and statistically significant effect on outgoing FDI. For incoming FDI, the effects are not significant even though the positive coefficients are large, due to large standard errors in the estimates. 
The second approach uses a stylized macroeconomic model of multinational firm production, extended to account for the totalization agreements' effects on firms' incentives. The international relocation of managerial effort depends on the differences across countries in terms of taxes on foreign managers, factor endowments, and the relative country-specific productivity.

That model, summarized in Appendix II, assumes that totalization agreements lower the cost of relocating labor abroad and American firms can use their know-how in foreign subsidiaries and branches by sending managerial capacity abroad. These international movements of managerial efforts allow American firms to expand their multinational production. The model shows that such an agreement, by decreasing the cost of relocating productive inputs across borders, increases the flows of foreign capital and investments that a country receives.

The share of foreign firm-embedded production in a host country is higher when the country is more productive, when it has more capital and labor and less managerial capacity relative to the source country, when the taxes on foreign management are lower in the host country, and when the taxes on own management are higher in the source country. As a result, the FDI flows of U.S. firms increase with the enactment of totalization agreements. The model predicts that the increase in the share of foreigncontrolled capital in a (host) country, given a decrease in the tax on foreign managers in that country, will be higher the more productive is the host country's economy, the less productive is the source country, the higher is the ratio of the workforce size in the host country relative to the source country, and the higher is the source country's tax on local managers. 
Table 4.9 shows quantitative examples of the sensitivity of the change in the share of foreign-controlled capital in partner countries due to the implementation of a totalization agreement. It reflects the results from simulations of equilibria with and without totalization agreement with two U.S. partner countries, Germany and Chile. The exercise for Chile uses data at the moment of the agreement's signing in 2001 to simulate the impact of the treaty. Because the treaty with Germany was enacted in 1979 and not all the necessary data is available for that year, we use data from 2015 to simulate the effects of removing the agreement. In these cases, the model indicates that totalization agreements with the U.S. led to an increase in the net FDI of the U.S. to these partner countries. The results from these simulations indicate that the profits of American firms engaged in additional multinational production are $15.6 \%$ and $7.3 \%$ higher as a consequence of the totalization agreements with Chile and Germany, respectively.

These examples show the change in the net flow of FDI with respect to the host country's capital stock (variable $s$ in the model) due to a totalization agreement. Table 4.9 also shows how sensitive that change in $s$ is with respect to the host country's productivity and its local tax on managers.

By decreasing the costs of sending workers abroad, totalization agreements affected American firms' incentives to relocate production abroad. Because payroll taxes are higher in Germany than Chile, this channel through which the agreements affect FDI is stronger in the case of U.S. investments in Germany than with Chile. Presumably because of this, the effect of a totalization agreement with that country is more sensitive to payroll taxes and productivity than the case of Chile. 
Table 4.9: Sensitivity of changes in share of U.S. FDI to partner countries' level of productivity and payroll taxes

\begin{tabular}{|c|c|c|c|c|c|c|}
\hline \multirow[b]{2}{*}{$\begin{array}{l}\text { Partner } \\
\text { country }\end{array}$} & \multirow[b]{2}{*}{$\begin{array}{l}\text { GDP } \\
\text { with } \\
\text { respect } \\
\text { to the } \\
\text { U.S. }\end{array}$} & \multirow[b]{2}{*}{$\begin{array}{l}\text { Share of } \\
\text { U.S.- } \\
\text { controlled } \\
\text { capital (s) } \\
\text { in data }\end{array}$} & \multirow[b]{2}{*}{$\begin{array}{l}\text { Additional } \\
\text { profits from } \\
\text { multinational } \\
\text { production } \\
\text { of American } \\
\text { firms due to } \\
\text { totalization } \\
\text { agreements }\end{array}$} & \multicolumn{3}{|c|}{$\begin{array}{l}\text { Change (percent) in } s \text { due to totalization } \\
\text { agreement }\end{array}$} \\
\hline & & & & $\begin{array}{l}\text { As } \\
\text { implemented }\end{array}$ & $\begin{array}{l}\text { Varying host } \\
\text { country's } \\
\text { productivity } \\
(+/-25 \%)\end{array}$ & $\begin{array}{l}\text { Varying } \\
\text { host } \\
\text { country's } \\
\text { local tax } \\
\text { (+/- } 2 \text { p.p.) }\end{array}$ \\
\hline Chile & 0.017 & $\begin{array}{l}1.44 \% \\
\text { (pre- } \\
\text { agreement) }\end{array}$ & $+15.6 \%$ & $\begin{array}{l}2.81 \% \\
(=0.04 \text { p.p. })\end{array}$ & $\begin{array}{l}(2.80 \% \\
2.83 \%)\end{array}$ & $\begin{array}{l}(2.41 \% \\
3.22 \%)\end{array}$ \\
\hline Germany & 0.21 & $\begin{array}{l}0.3 \% \\
\text { (post- } \\
\text { agreement) }\end{array}$ & $+7.3 \%$ & $\begin{array}{l}6.41 \% \\
(=0.02 \text { p.p.) }\end{array}$ & $\begin{array}{l}(6.14 \% \\
6.72 \%)\end{array}$ & $\begin{array}{l}(5.21 \%, \\
7.51 \%)\end{array}$ \\
\hline
\end{tabular}

Note. p.p. $=$ percentage points.

The quantitative exercises in Prados et al. (2019) indicate that the totalization agreement with Japan increased the incentives of Japanese firms to reallocate their operations to the U.S., resulting in net inward investment flows from Japan to the U.S. For Chile, however, the totalization agreement made it more profitable for American firms to send managers and investments to their Chilean affiliates. These exercises indicate that the direction of the net effect depends on the partner country's relative characteristics. The counterfactual exercise with Germany simulated the effects of removing the existing totalization agreement. This simulation predicts that if the agreement were removed, U.S. firms would decrease their investments in their German affiliates and German firms would increase flows of capital and investment to the U.S. The results suggest that this agreement almost evens out German investments in the U.S. and U.S. investments in Germany (due to the channels considered within the model), preventing the U.S. from being a net receptor of German investments. 
These exercises indicate that totalization agreements with Germany and Chile contributed to a decrease of the U.S. trade balance and an increase of the U.S. capital account and Gross National Product, which implies an increased domestic absorption due to the extra payments from factors abroad. According to these exercises, the totalization agreement with Japan had the opposite effect: It increased the U.S. trade balance, decreased the U.S. capital account and decreased U.S. domestic absorption.

Overall, the admittedly scarce literature seems to suggest we should expect macroeconomic effects from the totalization agreements. The literature, however, provides weak evidence on which to base the quantification of the benefits to the overall population. There are two reasons for this: First, the estimates of the macroeconomic impacts are both imprecise and uncertain. Second, the effects of aggregate changes are not straightforward to add to the cost-benefit calculations because the valuation after eliminating double-counting is not obvious; it would depend on the weight given to the economy's different stakeholders.

However, it does seem safe to conclude that there are some impacts that would increase the ratio of benefits to costs. We suggest considering adding such values with a large margin of error, and assessing the extent to which the overall conclusion of the cost-benefit analysis at hand remains robust.

\section{Summary of estimates}

Chapter 4 had two purposes: provide some examples of estimates for existing agreements as well as provide some discussion of how estimates could be obtained for prospective analyses. Throughout Chapter 4 , we were careful to describe the caveats of the estimates we have produced. Here, we provide a summary of these estimates, 
which we use to illustrate how these can be pulled together. The objective is not to emit some judgement about a particular agreement, but rather to show what can be done with what we currently know.

Take the case of Germany, which we illustrate with Table 5.1 below. We estimated the following direct benefits: $\$ 183.1$ million for always takers and their firms, a number that we showed was very similar to what was obtained from our example micro model; $\$ 25.3$ million also for this group from the reduction of income tax from the additional compensation (Table 4.2); and $\$ 73.1$ million for former workers who are able to "totalize" their benefits (Table 4.8). In addition, we estimate a benefit for induced expatriates of between $\$ 0$ and $\$ 54$ million, with a midpoint of $\$ 27$ million (Table 4.7) However, we know this is very tentative due to a lack of a solid estimate on the number of induced workers. On the cost side, we estimate the SSA would face foregone revenue of $\$ 158.8$ million from German always taker expatriates (Table 4.5) and $\$ 73.1$ million for totalized benefits. The federal government would lose an extra $\$ 23.9 \mathrm{M}$ from foregone income tax revenue from the reduction in compensation (Table 4.6). Overall, we have accounted for a total benefit for U.S. stakeholders of $\$ 309$ million, which surpasses the total cost of $\$ 256$ million. To the extent that we expect the macroeconomic impacts to be a net-positive due to the efficiency gains discussed earlier, this would lend support for the idea that benefits would surpass costs, though of course the extent of that difference depends on the magnitude of the benefits from the macro gains. This analysis is summarized in Table 5.1 below. 
Table 5.1 Summary of estimated benefits and costs, the case of Germany.

\begin{tabular}{|c|c|c|c|}
\hline \multirow[b]{2}{*}{ Effect group } & \multicolumn{3}{|c|}{$\begin{array}{l}\text { Benefits and costs for home-country stakeholders (millions of U.S. } \\
\text { dollars) }\end{array}$} \\
\hline & $\begin{array}{l}\text { U.S. expats and } \\
\text { their employers; and } \\
\text { former workers }\end{array}$ & $\begin{array}{l}\text { Social Security } \\
\text { Administration + } \\
\text { Government } \\
\text { revenue }\end{array}$ & U.S. population at large \\
\hline $\begin{array}{l}\text { Direct impacts } \\
\text { (absent behavior } \\
\text { change }\end{array}$ & $\begin{array}{l}183.1+ \\
25.3+ \\
73.1\end{array}$ & $\begin{array}{l}158.8+ \\
23.9+ \\
73.1\end{array}$ & -- \\
\hline $\begin{array}{l}\text { Impacts for } \\
\text { "induced" expats }\end{array}$ & 27 & -- & -- \\
\hline $\begin{array}{l}\text { Macroeconomic } \\
\text { effects: Trade, FDI } \\
\text { and others }\end{array}$ & & & $\begin{array}{l}\text { Evidence of incremental economic } \\
\text { activity, no reliable quantitative } \\
\text { impacts. }\end{array}$ \\
\hline
\end{tabular}

Of course, cost-benefit analyses do not always give clear cut answers on whether the benefits of an agreement will be higher than the costs for a country's stakeholders. One could do an analysis like the one above for a fictional country that sends many more people to the U.S. than vice-versa. A situation like this would most likely result in the costs from foregone revenue to SSA to be much higher than the benefits to the lower number of American always takers and induced expatriates. Still, even in this case, it is possible that efficiency gains may result in an overall benefit if the macroeconomic gains are large enough.

The following chapter identifies the knowledge gaps that would help to fill the unknowns and produce better cost-benefit analyses.

\section{Knowledge gaps}

According to the framework, we have identified a number of areas for which there is substantial knowledge and areas where there has been more limited research. With the existing research and data, it is possible to assess the benefits and costs to the 
always takers workers and the fiscal position of the social security programs. With lesser certainty, it is also possible to assess the effects on a number of macroeconomic outcomes.

As part of this research, we aimed to cover the gap by providing some estimates of induced workers' benefits. However, to obtain a value for the matrix cell corresponding to "induced" expatriate workers, it is necessary to have an idea of the totalization agreements' effects on worker flows. While prior research (Prados et al., 2019) attempted to estimate this through difference-in-difference regression techniques, that methodology was not able to detect an effect statistically different from zero. If the effect is indeed zero, then the cost-benefit analysis is substantially simplified. From those results, however, one cannot rule out effects below the threshold for statistical significance. Hence, there is a need for further research into totalization agreements' impacts on the magnitude of the worker flows. While, the differencein-differences approach has perhaps been exhausted, there may be some other approaches that may prove to be successful. One avenue may be case-study approaches looking at data for individual firms with operations in countries with recently signed agreements.

Strong assumptions are currently needed to estimate the cost to the foreign country's social security institutions from the totalization provision disbursements. More research into that would aid in more accurately assessing the benefit from that provision to American beneficiaries. 


\section{Conclusions}

We have provided a detailed framework for the analysis of costs and benefits of totalization agreements. We have identified the main stakeholders and their direct and indirect cost and benefit components. We believe this framework may be helpful for analysts and policymakers in evaluating current and prospective totalization agreements. By summarizing what is known in terms of research and data, and by putting it together in a cost-benefit framework, this work may help in the assessment of potential impacts, depending on the partner country's characteristics and how they affect different stakeholders.

We have illustrated the approach with tentative calculations for the agreements with Germany and Chile. These were done for illustration purposes and depend on strong assumptions and simplifications. A thorough evaluation of a specific existing or proposed agreement would ideally be based on richer information than we had access to. We have identified likely impacts of these agreements and the research gaps most important for conducting a cost-benefit analysis, which may serve as a roadmap for future research.

While we do not know everything that would be needed to conduct a full cost benefit analysis, we know enough to produce estimates of costs and benefits to fill a substantial fraction of the cost-benefit framework. In some cases, this will be enough to lead to clear conclusions about whether benefits are high enough to justify the costs of enacting a cost-benefit analysis. As always, there are trade-offs: some stakeholders will benefit while others are worse off by the introduction of the agreement. Determining whether the benefits outweigh the costs is outside the scope of our report. But the 
considerations and calculations outlined in this report may provide decision makers with the background needed to make these evaluations.

Cost-benefit analyses are of interest from a positive rather than normative perspective, too. Using a framework the one we developed here can help identify where most of the benefits and the costs lie and explain different positions regarding particular agreements. 


\section{References}

Abadie, A., \& Gardeazabal, J. (2003). The economic costs of conflict: A case study of the Basque Country. American economic review, 93(1), 113-132.

Angrist, J. D., Imbens, G. W., \& Rubin, D. B. (1996). Identification of causal effects using instrumental variables. Journal of the American Statistical Association, 91, 444-455.

Bonache, J., \& Zárraga-Oberty, C. (2017). The traditional approach to compensating global mobility: criticisms and alternatives. International Journal of Human Resource Management, 28, 149-169.

BGRS (2016). 2016 Global mobility trends survey: Breakthrough to the future of global talent mobility. http://globalmobilitytrends.bgrs.com/assets2016/downloads/FullReport-BGRS-2016-Global-Mobility-Trends-Survey.pdf

Carey, B. P. (1993). Why inpatriates need special remuneration packages. The Journal of European Business, 4(5), 46.

Costinot, A., \& Rodríguez-Clare, A. (2014). Trade theory with numbers: Quantifying the consequences of globalization. In Handbook of international economics (Vol. 4, pp. 197-261). Elsevier.

Fonseca, R., Michaud, P.-C., Galama, T., \& Kapteyn, A. (2020). Accounting for the rise of health spending and longevity. Journal of the European Economic Association. (in press)

French, E. (2005). The effects of health, wealth, and wages on labour supply and retirement behaviour. Review of Economic Studies, 72, 395-427.

Gustman, A. L., \& Steinmeier, T. L. (2009). How changes in Social Security affect recent retirement trends. Research on Aging, 31, 261-290. 
International Labour Organization [ILO] (2017). World Social Protection Report 2017-19:

Universal social protection to achieve the Sustainable Development Goals. Geneva: International Labour Office. http://ilo.org/global/publications/books/WCMS_604882/lang--en/index.htm

Jackson, B. W., \& Cash, S. (2018). Social Security Bulletin, Vol. 78, No. 4.

Karoly, L. A., \& Perez-Arce, F. (2016). A Cost-Benefit Framework for Analyzing the Economic and Fiscal Impacts of State-Level Immigration Policies. Research Report No. RR-1397-MCF. Santa Monica, CA: RAND Corporation. https://doi.org/10.7249/RR1397

KPMG International (2019). Global assignment policies and practices survey: 2019 results.https://home.kpmg/gappsurvey

Larkins, E. R. (1993). The Dual Benefits of Totalization Agreements for United States Citizens Employed Abroad. Willamette L. Rev., 29, 5.

Pattison, D. (2015) Social Security trust fund cash flows and reserves. Social Security Bulletin, 75(1), 1-34.

Prados, M., Meijer, E., \& Perez-Arce, F. (2019). The effects of totalization agreements on economic activity. Michigan Retirement and Disability Research Center Working Paper, WP 2019-407.

Ramondo, N., \& Rodríguez-Clare, A. (2013). Trade, multinational production, and the gains from openness. Journal of Political Economy, 121(2), 273-322.

Russo, S. M., \& D'Onofrio, S. F. (1995). How to Reduce International Assignment Costs Through International Social Security Agreements. Int'l Tax J., 21, 86.

Scholz, J. K., Seshadri, A., \& Khitatrakun, S. (2006). Are Americans saving "optimally" for retirement? Journal of Political Economy, 114, 607-643. 
Seshadri, A. (2019). Estimating the Effects of the Totalization Agreements. Michigan Retirement and Disability Research Center Working Paper, WP 2019-403.

Social Security Administration (2018a). Annual Statistical Supplement to the Social Security Bulletin. Available on the web at https://www.ssa.gov/policy/docs/ statcomps/supplement/.

-; - (2018b). Social security programs throughout the world: Europe, 2018. SSA Publication No. 13-11801. Washington, DC.

—; - (2018c). Social security programs throughout the world: The Americas, 2017. SSA Publication No. 13-11804. Washington, DC.

Suutari, V., \& Tornikoski, C. (2001). The challenge of expatriate compensation: the sources of satisfaction and dissatisfaction among expatriates. International Journal of Human Resource Management, 12, 389-404.

Warneke, D., \& Schneider, M. (2011). Expatriate compensation packages: what do employees prefer? Cross Cultural Management, 18, 236-256. 


\section{Appendix I. Description of the model of individual international}

\section{workers}

As emphasized in the text, this model is highly stylized, but nevertheless contains several aspects that are relevant for modeling effects a totalization agreement's on the individual. The model focuses on a U.S.-based worker who may temporarily work in a foreign country during part of their working life. As is common in this type of model, we assume the individual maximizes lifetime utility, which in our model is

$$
V_{0}=\sum_{a=0}^{T-1} \beta^{a} \frac{\left[\left(1-\phi L_{a}\right)\left(1-\omega F_{a}\right) c_{a}\right]^{1-\gamma}}{1-\gamma},
$$

where $a$ is age (normalized such that $a=0$ when entering the labor force, although this is only for notational convenience), $T$ the length of life, $\beta$ the discount factor, $c_{a}$ is consumption, $\gamma$ is the reciprocal of the intertemporal elasticity of substitution (higher values of this mean stronger preferences for smooth consumption patterns across the life cycle), $L_{a}$ is an indicator for whether one works (1) or not (0), and $F_{a}$ is an indicator for whether one temporarily works in a foreign country (1) or not (0). The parameter $\phi$ reflects the disutility of working and $\omega$ reflects the disutility (or utility, if negative) of being on a temporary foreign assignment. Our model assumes that the individual works in each period before retirement age $R$ and does not work (is retired) from age $R$ onward, and that the individual starts claiming Social Security at the same time as retiring. The model contains a standard equation for returns on assets and the budget constraint that assets at the end of life need to be zero (or positive), but no other borrowing constraints.

The model requires as input a sequence of gross earnings at each age (if the individual would work at that age). Net earnings are obtained from slightly simplified 
formulas reflecting U.S. federal income and payroll taxes in 2019, preserving progressivity of income taxes and the Social Security taxable maximum, as well as potential foreign payroll taxes. It assumes that the U.S. has an income tax treaty with the foreign country, with foreign income tax rates not exceeding U.S. income tax rates, so the total amount of income tax is equal to the income tax liability if the individual worked in the U.S. with the same earnings. It would be fairly straightforward to modify the code to accommodate additional foreign income taxes as well.

Social Security benefits are calculated using (1) a slightly simplified average indexed monthly earnings (AIME) formula, in which indexation and cost of living adjustments are absent (so the model is in real, rather than nominal, dollars, and it is assumed that growth of the average wage is the same as inflation), (2) the resulting primary insurance amount (PIA), and (3) the applicable adjustments for early or late claiming, depending on claiming age $R$. The model assumes that the individual is not eligible for foreign Social Security benefits. Private pensions are not explicitly included in the model, so they are implicitly assumed to be part of assets, that is, a defined contribution type, (e.g., 401(k)), without modeling the differential tax treatment of such plans compared to, say, regular savings accounts.

We calculate the individual's optimal decisions given the model, its parameters, and the auxiliary inputs. These decisions entail retirement age $R$ and consumption in each period, $c_{a}$. Savings, assets, taxes paid, benefits received, and utility are computed as functions of the inputs and the optimal decisions. If the individual has a choice regarding whether to accept the foreign assignment or not, we can compute lifetime 
utility with and without the foreign assignment and then accept or decline the foreign assignment depending on which has higher lifetime utility.

We can find the extra compensation needed if any for a foreign assignment by finding the (minimal) percentage earnings increase during the foreign assignment necessary such that the individual prefers the foreign assignment. We can do this separately without a totalization agreement and with such an agreement, which gives us the earnings during the assignment with and without TA. We also can find the effects for the always takers by calculating the employer cost (earnings and employer part of payroll taxes) in both cases and their difference.

If the employer is unable or unwilling to pay the additional earnings and taxes for the worker, the worker stays in the U.S. The introduction of the TA can then shift the balance, leading to the induced worker effect.

We used this model for some of the illustrative calculations presented in the main text, as indicated there. For these calculations, we took typical values of the parameters as found in the literature, or adaptations thereof that better reflected the (higher) incomes of typical U.S. expatriates, as discussed in the text. The only parameter for which we have not derived a value from the literature is the foreign assignment's $\operatorname{disutility}(\omega)$. This likely varies greatly between individuals and depends on many factors, including purchasing power in the partner country and other characteristics that may make certain countries attractive and others unattractive. Therefore, in the text, we report calculations based on different values of this parameter to illustrate the range of results one may find. 


\section{Appendix II. Results from the model of multinational production}

The model in Prados et al. (2019) assumes there is a single, freely traded consumption good produced by firms using capital services, labor services, and leadership. There are two types of employees in a firm: workers (who provide the labor services) and managers (who make decisions for the firm and provide know-how and management skills). We reproduce here the model specifications for convenience.

The output of a firm that has $x$ units of management know-how, I units of labor, and $k$ units of physical capital, and is operating in country $i$ is given by $y=$ $Z_{i} x_{i}^{v}\left(k^{\alpha} l^{1-\alpha}\right)^{1-v}$, where $v \in(0,1)$ is the share of management know-how in output and $\alpha(1-v) \in(0,1)$ is the share of physical capital in output. The term $Z_{i}$ reflects the country-specific productivity, as given by its infrastructure, laws and regulations, human capital levels, and other nontradeable aspects that affect production possibilities. Management skills $x$ determine firm-specific productivity, and can be allocated across countries. When a firm from country $j$ sends firm-embedded productivity to country $i$, it produces output $y=Z_{i} x_{j}^{v}\left(k^{\alpha} l^{1-\alpha}\right)^{1-v}$. Firms profits are $\pi_{i}$ for locations in country $i$ and $\pi_{j}$ for affiliates in country $j$.

Assuming that there are two countries, $i$ and $j$, and all firms are homogeneous, aggregate output in country $i$ is: $Y_{i}=Z_{i} \bar{X}_{i}^{v}\left(\bar{K}_{i}^{\alpha} L_{i}^{1-\alpha}\right)^{1-v}$, where $\bar{X}_{i}$ represents the total net managerial power used in country $i$ and $\bar{K}_{i}$ is the total physical capital operating in country $i$. In equilibrium, the wage for workers is $w_{i}=(1-\alpha)(1-v) Y_{i} / L_{i}$, the price of managerial know-how is given by firms' profits $\pi_{i}=v Y_{i} / X_{i}$, and the rental rate for capital is $r_{i}=\alpha(1-v) Y_{i} / K_{i}$. 
Due to international mobility of managers and capital, $\bar{X}_{i}$ and $\bar{K}_{i}$ may be smaller or larger than the country's endowments, $X_{i}$ and $K_{i}$. Analogous notation applies to country $j$. To obtain stylized results, we consider a simplified model in which the world consists of two countries. The two-country aggregate constraints for these factors are: $\bar{X}_{i}+\bar{X}_{j}=X_{i}+X_{j}$, and $\bar{K}_{i}+\bar{K}_{j}=K_{i}+K_{j}$.

The worldwide equilibrium allocates management know-how by equalizing its net-of-tax marginal product across countries. The allocation of managerial effort across countries depends on their differences in terms of taxes on foreign managers, factor endowments, and the relative country-specific productivity. Totalization agreements affect the tax burden of multinational production in this model and, thus, the international allocation of management.

In an interior equilibrium where country $i$ exports firm-embedded productivity to country $j$, net-of-tax profits for managers from country $i$ must be equal across both countries. In such an equilibrium, we define $X_{i j}$ implicitly, and the share of firmembedded productivity in country $j$ controlled by foreign firms is: $s=\frac{X_{i j}}{\bar{X}_{j}}=\frac{\bar{X}_{j}-X_{j}}{\bar{X}_{j}}$

If the country $i$ is a net source of managerial power, i.e., $X_{i j}>0$, absorption (consumption plus investment) equals aggregate output minus the net payments to foreign factors: $C_{i}+\delta \bar{K}_{i}=Y_{i}+\left(1-\tau_{j}^{F}\right) s v Y_{j}+r^{*}\left(K_{i}-\bar{K}_{i}\right)$. The trade balance of country $i$ is given by: $T B_{i}=-\left(1-\tau_{j}^{F}\right) s v Y_{j}-r^{*}\left(K_{i}-\bar{K}_{i}\right)<0$, if $X_{i j}>0$. Thus, the model predicts that countries with net FDI outflows run a trade balance deficit as they have to make payments to foreign factors. Conversely, the country with the net FDI inflows runs a trade balance surplus with its partner country. 